\title{
OUTCOMES OF ENTREPRENEURSHIP EDUCATION: AN INSTITUTIONAL PERSPECTIVE
}

\author{
DR. SASCHA G. WALTER (CORRESPONDING AUTHOR) \\ Reader in Entrepreneurship and Innovation \\ Lancaster University \\ Lancaster, LA1 4YX, UK \\ Tel: +44 1524594847 \\ Fax: +44 1524594847 \\ Email: s.walter@lancaster.ac.uk \\ DR. JÖRN HENDRICH BLOCK \\ Professor of Management \\ University of Trier \\ Trier, 54296, Germany \\ Tel: +496512013030 \\ Fax: +496512013029 \\ Email: block@uni-trier.de
}

\begin{abstract}
Drawing on institutional theory and the model of entrepreneurial action, we build and test a multilevel model on the outcomes of entrepreneurship education. Essentially, we suggest that entrepreneurship education has stronger relationships with subsequent entrepreneurial activity in seemingly entrepreneurship-hostile institutional environments. Findings from 11,230 individuals in 32 countries support this notion. The results have implications for researchers and practitioners in the field of entrepreneurship education.
\end{abstract}

Keywords: entrepreneurship education, entrepreneurial activity, model of entrepreneurial action, institutional theory, multilevel analysis

JEL: D83, L24, L26, M13

Acknowledgements: The authors gratefully acknowledge the very constructive feedback of our field editor, Maria Minniti, and three anonymous reviewers. We also thank Sarah Jack for valuable comments on prior versions of the paper.

A later version will be published as: Walter, S. G. \& Block, J. H. (forthcoming) Outcomes of Entrepreneurship Education: An Institutional Perspective. Journal of Business Venturing. 


\section{Introduction}

In the hope of sparking more entrepreneurship, many countries have substantially invested in entrepreneurship education at universities (Brush et al., 2003; Katz, 2003), high schools (EACEA, 2012; Peterman and Kennedy, 2003; Sánchez, 2013), and even primary schools (Huber et al., 2014). This has increased scholarly interest in the outcomes of such efforts (Dickson et al., 2008; Gorman et al., 1997; Pittaway and Cope, 2007). While most studies suggest that entrepreneurship education fosters entrepreneurial intentions and thus entrepreneurial activity (e.g., Kautonen et al., 2015; Peterman and Kennedy, 2003; Rauch and Hulsink, 2014; Sánchez, 2013; Souitaris et al., 2007; Walter et al., 2013), there is also evidence of a negative, discouraging effect of entrepreneurship education (Oosterbeek et al., 2010; von Graevenitz et al., 2010). These mixed findings could indicate that environmental contingencies condition the outcomes of entrepreneurship education (De Clercq et al., 2013; Walter and Dohse, 2012). ${ }^{1}$ Indeed, scholars have long viewed entrepreneurship as a result of a person-context interaction (Learned, 1992; Herron and Sapienza, 1992; Naffziger et al., 1994) and recent meta-analyses have warranted more research into potential moderators of education effects (Bae et al., 2014; Martin et al., 2013; Unger et al., 2011). However, to date, there is little research into this direction (Pittaway and Cope, 2007), although it promises interesting insights into how entrepreneurial decision-making is embedded in the national context (Shepherd, 2011).

To address this gap, our study explores how the relationship between entrepreneurship education, i.e., the degree to which an individual believes that such education has successfully formed her entrepreneurial attitudes and skills, and entrepreneurial activity, i.e., the likelihood of being self-employed at a given time, is conditioned by a country's institutional

1 De Clercq et al. (2013) found that institutions in a country moderate the relationship between an individual's human capital and the likelihood of starting a new business. Walter and Dohse (2012) showed that the effect of reflective, but not active modes of entrepreneurship education depends on the regional context. 
context. ${ }^{2}$ Drawing on institutional theory (North, 1990; Whitley, 1999) and the model of entrepreneurial action (McMullen and Shepherd, 2006), we posit that entrepreneurship education stimulates entrepreneurial activity in entrepreneurship-hostile institutional environments rather than, as also seems intuitively plausible, in entrepreneurship-friendly institutional environments. Consistent with Whitley’s (1999; 2002) comparative business systems perspective, our study covers five characteristics of a country’s institutional profile, including entrepreneur-friendly regulations, financial capital availability, educational capital availability, control of corruption, and the public image of entrepreneurs. Specifically, we argue that these five institutional characteristics affect the monetary and non-monetary payoff of entrepreneurship and that in entrepreneurship-friendly institutional environments individuals can acquire entrepreneurial motivation and qualification also from other sources than entrepreneurship education.

Multilevel analyses of data from 11,230 individuals in 32 countries provide support for our arguments. Overall, this study bridges, theoretically and empirically, different levels of analysis by exploring how country-level institutions condition the effect of individual-level entrepreneurship education on subsequent entrepreneurial activity. The study makes two key contributions. First, prior empirical research on entrepreneurship education has been limited to the individual level and has—-typically as a matter of research design—factored out country-level influences (e.g., Rauch and Hulsink, 2014; Souitaris et al., 2007). Our findings extend this literature by showing that better understanding educational outcomes requires considering a country's institutional environment. This insight is also important for policymakers and educators who face increasing pressures to justify investments into education and to benchmark educational outcomes internationally (OECD, 2013; Oosterbeek et al., 2010).

\footnotetext{
2 Our definition of entrepreneurship education emphasizes the efficacy of formal education in nurturing entrepreneurial knowledge and motivation. It is therefore consistent with prior research on how taking entrepreneurship courses leads students to perceive entrepreneurship to be more feasible and/or desirable (Peterman and Kennedy, 2003; Sánchez, 2013). This self-perception is considered critical for start-up decisions (McMullen and Shepherd, 2006), but can deviate from educational attainment, which is a form of social perception.
} 
Second, our results contribute to the literature on institutions and entrepreneurship. Prior research in this field has illuminated how country-level institutions directly (e.g., Bowen and De Clercq, 2008; Lee et al., 2011) or interactively (e.g., Kim and Li, 2014) shape entrepreneurial activity. This study adds to this literature by providing evidence for the role of individual-level entrepreneurship education in this context. It also highlights that combining theory from different level of analysis can further our understanding of how entrepreneurship education and the institutional environment interact in promoting entrepreneurial activity.

\section{Theory development}

Institutional theory seeks to explain how and why countries differ in the way that economic activities are organized and undertaken (Whitley, 1999). Institutions-“"the humanly devised constraints that structure human interaction" (North, 1990: 3)—define rules and norms, with which individuals and organizations tend to comply to sustain their positions and legitimacy (Bruton et al., 2010). Institutional theory has been acknowledged as a powerful perspective to examine various phenomena, including the cross-country variance in entrepreneurial activity (e.g., Bruton et al., 2010; Jennings et al., 2013; Minniti, 2008; Welter and Smallbone, 2011). Baumol (1990: 894) notes, “[h]ow the entrepreneur acts at a given time and place depends heavily on the rules of the game-the reward structure in the economy”. Institutions also play a key role in public policies intended to encourage more entrepreneurship within a country. The state designs and operates formal institutions, such as the legal system, and can indirectly influence informal institutions through its pronouncements and actions (Welter and Smallbone, 2011). As Minniti (2008) emphasizes, it is the influence on institutions what enables government policies to influence entrepreneurship. Indeed, the desire to promote innovation and reduce unemployment has led many countries to invest in an entrepreneurship-friendly institutional infrastructure in general (Minniti, 2008) and entrepreneurship education in particular (e.g., Brush et al., 2003; 
EACEA, 2012; Katz, 2003). How both aspects affect entrepreneurial activity has been explored in two different, relatively isolated research streams.

The first research stream, based on institutional theory (North, 1990; Whitley, 1999), focuses on how country-level institutions are conducive or unconducive to entrepreneurship. This effect of institutions is believed to operate via several mechanisms. For instance, institutions influence the transaction costs, risk, and uncertainty of entrepreneurial behavior (North, 1990; Mueller and Thomas, 2001). They define, create, and limit entrepreneurial opportunities (Baker et al., 2005; Urbano and Alvarez, 2014). They regulate the accumulation and appropriability of the returns from entrepreneurship and innovation (Autio and Acs, 2010; Levie and Autio, 2011). Empirical research has linked entrepreneurial activity to various institutions, such as state incentives (Meek et al., 2010), bankruptcy laws (Lee et al., 2011), the financial system (Bowen and De Clercq, 2008), the legal system (Lim et al., 2010), the educational system (De Clercq et al., 2013), property rights (McMullen et al., 2008), economic freedom (Gohmann, 2012), corruption control (Anokhin and Schulze, 2009), and a supportive infrastructure (Begley et al., 2005). While many of these studies imply that entrepreneurship-friendly institutions may directly stimulate entrepreneurial activity, a few studies argue that the opposite can also be true. Using an African country context, Frese et al. (2007) and Gielnik et al. (2015) motivate their research by proposing that weak institutions can lead to need-driven entrepreneurship activities. In a study by Kim and Li (2014), individuals were less likely to start a business in countries with a stronger rule of law.

The second research stream explores how entrepreneurship education drives intended or actual career choices (Dickson et al., 2008; Gorman et al., 1997; Pittaway and Cope, 2007). This research focuses on the individual level. Entrepreneurship education can include extracurricular and curricular offerings that are either integrated into other subjects or constitute 
separate subjects (EACEA, 2012; Huber et al., 2014). ${ }^{3}$ The literature has highlighted several advantages of entrepreneurship education. For instance, individuals learn to more effectively or rapidly bring business ideas to market than others, or at least feel more capable of doing so (Peterman and Kennedy, 2003). The existence of entrepreneurship education can signal the desirability of entrepreneurship and therefore sensitize students to entrepreneurial careers (Walter et al., 2013). In fact, most studies have indicated that taking entrepreneurship courses (e.g., Athayde, 2009; Peterman and Kennedy, 2003; Sánchez, 2013; Souitaris et al., 2007) or their mere existence (Walter et al., 2013; Walter and Dohse, 2012) shapes interest in entrepreneurial careers. Other studies suggest negative, discouraging effects, arguably because entrepreneurship students obtain a more realistic perspective on their own entrepreneurial abilities and preferences and the requirements of successful entrepreneurial careers (von Graevenitz et al., 2010; Oosterbeek et al., 2010). Recent meta-analyses find positive overall effects of entrepreneurship education on human capital assets and entrepreneurship outcomes (Bae et al., 2014; Martin et al., 2013). Yet, they report considerable heterogeneity in prior findings and interpret this as a sign of potential moderators. Because some of the differences appear to reflect institutional differences, institutional theory may be a promising starting point to identify such moderators at the country level (Bruton et al., 2010; Peng et al., 2008; Shepherd, 2011). ${ }^{4}$

To guide our selection of institutional characteristics, we draw on Whitley’s (1999; 2002) comparative business systems perspective. This framework has been advocated for

${ }^{3}$ Extra-curricular offerings are often based on programs, such as BizWorld for primary schools (Huber et al., 2014), Young Achievement Australia (Peterman and Kennedy, 2003) for secondary schools and EXIST (Kulicke, 2014) for universities. In the curricula of primary and secondary schools, entrepreneurship education tends to be integrated into other subjects but is also taught as a separate subject (EACEA, 2012). Many universities provide curricular entrepreneurship courses (Souitaris et al., 2007) or specialized MSc programs (Rauch and Hulsink, 2014).

${ }^{4}$ In the overview by Martin et al. (2013: 216), several published studies investigated the relationship between entrepreneurship education and entrepreneurial intentions. For countries with entrepreneurship-hostile institutions, including Poland, South Africa and Tanzania, the relationship was homogenously positive (also cf. Gielnik et al., 2015), whereas it was partly positive, partly negative in countries characterized by entrepreneurship-friendly institutions, including Australia, France, Germany, the Netherlands, the United Kingdom, and Spain. 
considering a comprehensive set of institutions and for offering a clear link between a country’s institutional profile and entrepreneurial activity (Bowen and De Clercq, 2008; Lim et al., 2010). Essentially, Whitley suggests four groups of institutional factors to explain the organization of economic activity within a country: (1) the state, e.g., the extent of formal market regulations, (2) the financial system, e.g., the process by which capital is made available and priced, (3) the skill development and control system, e.g., the education and training system, and (4) norms and values governing trust and authority relationships. Using Whitley's framework, we formulate hypotheses for the contingent effect of five institutions, namely entrepreneur-friendly regulations, financial capital availability, educational capital availability, control of corruption, and the public image of entrepreneurs.

According to the theory of entrepreneurial action (McMullen and Shepherd, 2006), the decision to exploit an entrepreneurial opportunity is determined by an individual's beliefs regarding whether she can achieve the expected outcomes with that opportunity and whether this attainment fulfills the individual's original motive. In other words, entrepreneurial activity results from a belief that successfully exploiting a given opportunity is both feasible and desirable. ${ }^{5}$ Education can play a central role in this context. As McMullen and Shepherd (2006: 141) note, “[...] through learning efforts and/or the encouragement of others, one may be able to overcome doubt and act [on a given opportunity]”. Similarly, prior research has revealed that entrepreneurship courses make the participants perceive entrepreneurial activity to be more feasible and/or more desirable (Athayde, 2009; Souitaris et al., 2007). Entrepreneurship education is believed to raise interest in entrepreneurial careers by transferring basic entrepreneurial knowledge and motivation (Huber et al., 2014; Peterman and Kennedy, 2003; Sánchez, 2013), by shaping critical aspects of an individual’s occupational self-concept (Armstrong and Crombie, 2000), and by boosting post-school entrepreneurial learning (Cunha and Heckman, 2007; Huber et al., 2014).

\footnotetext{
${ }^{5}$ Our theorizing focuses on the 'evaluation stage' of McMullen and Shepherd's (2006) model as this stage directly portrays the decision to engage in entrepreneurial action.
} 
Two theoretical mechanisms can explain why institutions condition the impact of entrepreneurship education. ${ }^{6}$ First, the relative importance of entrepreneurship education varies across institutional environments. It is more critical in entrepreneurship-hostile institutional environments, where institutional barriers to start-up activity are higher and alternatives to entrepreneurship education are not readily available elsewhere. ${ }^{7}$ Second, institutions influence the relative utility, i.e., the monetary and non-monetary pay-offs that an individual can derive from pursuing an entrepreneurial career vis-à-vis alternative careers (Baker et al., 2005; Douglas and Shepherd, 2002; Eisenhauer, 1995; Lévesque et al., 2002). In countries with underdeveloped institutions, entrepreneurship is often the utility-maximizing option (e.g., necessity entrepreneurship in Africa, Gielnik et al., 2015). These two mechanisms form the basis of our five hypotheses below.

\section{Hypotheses}

One important aspect of the institutional environment is the legal system in general and entrepreneur-friendly regulations in particular. The latter refers to legal provisions supportive of entrepreneurial activity, including start-up regulations (Stel et al., 2007), bankruptcy regulations (Lee et al., 2011), and intellectual property rights (McMullen et al., 2008). A strong legal system increases efficiency in business transactions and reduces transaction costs, thereby enabling individuals to profit from their business activities (Meek et al., 2010; Whitley, 1999). Enforceable property rights and efficient legal procedures to establish and dissolve a firm are conducive to start-up activity because they increase the value appropriable from an entrepreneurial opportunity (Baker et al., 2005). In contrast, unfavorable regulations are said to hamper entrepreneurial activity (Aidis et al., 2008). For instance, effective property

\footnotetext{
${ }^{6}$ Another possibility is that the general knowledge provided by entrepreneurship education is more suitable for the typical start-up activity in entrepreneurship-hostile than in entrepreneurship-friendly institutional environments.

7 One example of how entrepreneurship education can operate under 'difficult conditions', namely in prison, is provided by Patzelt et al. (2014).
} 
rights facilitate the formulation of a strategy to appropriate and protect value through an entrepreneurial opportunity — a task that is less straightforward in countries with insufficient legal property protection.

The effect of entrepreneurship education on entrepreneurial activity should be stronger in countries with entrepreneur-hostile regulations. In this environment, more persistence and know-how is needed to start a venture. Entrepreneurship education can lead individuals to perceive entrepreneurial activity as more feasible (Peterman and Kennedy, 2003; Sánchez, 2013). The better an individual feels equipped with entrepreneurial knowledge and motivation from entrepreneurship education, the more likely she has the confidence to overcome regulation-related barriers. Conversely, in countries with entrepreneur-friendly regulations, these barriers are lower. This facilitates entry into entrepreneurship also for individuals with no or low-quality entrepreneurship education, which, in turn, decreases the relationship between an individual's perceptions of entrepreneurship education and entrepreneurial activity.

Furthermore, a sound legal framework also supports the sustained economic growth of incumbents (North, 1990; Whitley, 2002). For instance, firms were found to be, on average, larger in countries where patents effectively safeguard property rights (Bowen and De Clercq, 2008; Kumar et al., 1999). If incumbents prosper in such environments, higher and more certain income and better social safety can be attained through wage-employment (Baker et al., 2005). In contrast, wage-employment is typically less well paid or unavailable in countries with entrepreneur-hostile regulations, making entrepreneurship an attractive alternative for someone who has acquired entrepreneurial motivation and knowledge through education (McMullen et al., 2008). In addition, many companies in Western countries, in particular those countries with entrepreneur-friendly regulations, have adopted corporate venturing practices to compete in the market for innovation (Covin and Miles, 2007). Entrepreneurs and 'intrapreneurs' are said to have great overlaps in their motivational profiles, sharing for 
instance a desire for independence (Kuratko et al., 2011:230-231). In other words, incumbents in these countries are more likely to offer jobs that satisfy many psychological needs of entrepreneurs, with a more certain income than entrepreneurship. Thus, in countries with entrepreneur-friendly regulations, some entrepreneurial potential created by entrepreneurship education is likely to flow to incumbents rather than resulting in start-up activity. Ceteris paribus, the effect of entrepreneurship education on entrepreneurial activity may become stronger, the lower the level of entrepreneur-friendly regulations:

Hypothesis 1. Entrepreneur-friendly regulations negatively moderate the positive relationship between entrepreneurship education and entrepreneurial activity.

Institutional environments vary in the extent to which they supply resources supportive of business activities. In some environments, abundant resources are available and enable newly created firms lacking slack resources to pursue resource-intensive strategies—a situation referred to as ‘environmental munificence’ (Begley et al., 2005; Rosenbusch et al., 2013). ${ }^{8}$ We focus on two aspects of environmental munificence derived from Whitley’s (1999) framework. The first aspect is financial capital availability, i.e., the degree to which entrepreneurs can access financial capital via bank loans, venture capitalists or the stock market (De Clercq et al., 2013). Access to external funding is critical for potential entrepreneurs to overcome personal liquidity constraints (Evans and Jovanovic, 1989). The second aspect is educational capital availability, i.e., the supply of skilled labor as reflected in the average educational level in a country (Lim et al., 2010). This aspect emphasizes general education, which has to be distinguished from specialized education that shapes specific mindsets and skills, such as entrepreneurship education (Bowen and De Clercq, 2008). Access to abundant financial resources and to high-quality human resources promotes founding

\footnotetext{
${ }^{8}$ We thank an anonymous reviewer for directing us to the munificence argument.
} 
decisions (Baker et al., 2005; De Clercq et al., 2013) and entrepreneurial performance (Millán et al., 2014).

We argue next that the link between entrepreneurship education and entrepreneurial activity is stronger in low-munificence countries. If acquiring key resources is impossible or only at high costs, exploiting a given entrepreneurial opportunity may appear less feasible (McMullen and Shepherd, 2006). The lower the environmental munificence in a country, the more critical the role of entrepreneurship education for feasibility perceptions becomes (Huber et al., 2014; Peterman and Kennedy, 2003; Sánchez, 2013). Similarly, demonstrating one’s competence through education, including entrepreneurship education, becomes more important in a country where competition for resources prevails (Unger et al., 2011). In contrast, in high-munificence countries, resource competition and thus the salience of entrepreneurship education decline, enabling also individuals with lacking or low-quality entrepreneurship education to enter entrepreneurship.

Environmental munificence may also affect the relative utility individuals gain from entrepreneurial activity vis-à-vis wage-employment. Meta-analytical research suggests that many existing firms respond to a munificent environment by being more entrepreneurially oriented and thus perform better (Rosenbusch et al., 2013). These firms are not only likely to pay higher wages compared with potential income from entrepreneurship, but they are also likely to offer intrapreneurship-like jobs that are interesting for entrepreneurial-minded individuals (Kuratko et al., 2011:230-231). Incumbents may therefore be attractive employers for individuals whose entrepreneurship education led them to value entrepreneurial careers more. However, in low-munificence countries, in which financial and educational capital are scarce, the same type of individuals may derive greater utility from entrepreneurial activity because entrepreneurial-oriented incumbents and thus offers of intrapreneurship-like jobs are 
less frequent. ${ }^{9}$ Thus, ceteris paribus, the effect of entrepreneurship education on

entrepreneurial activity may become stronger, the lower the level of financial and educational capital availability in a country:

Hypothesis 2. Financial capital availability negatively moderates the positive relationship between entrepreneurship education and entrepreneurial activity.

Hypothesis 3. Educational capital availability negatively moderates the positive relationship between entrepreneurship education and entrepreneurial activity.

Another critical aspect of institutions is control of corruption, i.e., the degree to which corruption — the abuse of public power for private gains, for instance through bribery—is constrained (Bowen and De Clercq, 2008; Lim et al., 2010). Corruption increases agency and transaction costs and thereby creates disincentives for investing into activities with uncertain or temporally distant payoffs, such as innovation and entrepreneurship (Anokhin and Schulze, 2009). Prior research has found that higher levels of corruption are associated not only with lower national welfare (Ehrlich and Lui, 1999), but also with lower firm growth and performance (Petrou, 2014). Since corruption poses additional risks and costs, incumbents in corruption-plagued countries are less willing and/or able to pay high wages and engage in corporate entrepreneurship. Intrapreneurship-like jobs are less likely to exist in these countries and entrepreneurship education leads individuals to become entrepreneurs rather than intrapreneurs.

${ }^{9}$ Entrepreneurship education could also enable individuals to effectively choose between alternative resources (e.g., bank loans vs. venture capital), thereby raising the potential value of a given opportunity. Moreover, if high-quality human resources are unavailable, a potential entrepreneur might refuse to pursue entrepreneurial opportunities despite entrepreneurship education. Both arguments suggest positive moderation effects of financial and education capital availability. 
In addition, corruption discourages entrepreneurship in a country to the extent to which corrupt officials misappropriate value from an entrepreneurial opportunity (Bowen and De Clercq, 2008). In the face of corruption, exploiting an opportunity may appear less feasible and/or less desirable (Anokhin and Schulze, 2009). However, an individual who have learned through entrepreneurship education that start-up barriers can be overcome is more likely to positively evaluate an opportunity despite corruption (Peterman and Kennedy, 2003; Sánchez, 2013). Individuals may also be more determined to exploit opportunities despite corruption, if entrepreneurship education has led them to integrate aspects of entrepreneurship into their occupational self-concept (Armstrong and Crombie, 2000). Conversely, in countries effectively controlling corruption, start-up barriers are lower and these advantages of entrepreneurship education are thus less salient. Ceteris paribus, the effect of entrepreneurship education on entrepreneurial activity may become stronger, the lower the control of corruption in a country:

Hypothesis 4. Control of corruption negatively moderates the positive relationship between entrepreneurship education and entrepreneurial activity.

Institutions can legitimize or delegitimize economic activity (North, 1990; Whitley, 1999). By defining social norms and values, they specify desired behaviors and sanctions for non-compliance (Meek et al., 2010). While entrepreneurship is a generally accepted and appreciated behavior in some countries, entrepreneurs face greater suspicion in other countries (Busenitz et al., 2000; Urbano and Alvarez, 2014). We therefore suggest the public image of entrepreneurs, i.e., the share of persons with a favorable opinion of entrepreneurs within a country, as a final boundary condition for the effect of entrepreneurship education. In countries that value entrepreneurial activity, an individual is exposed to entrepreneurshipfriendly attitudes also outside school or university boundaries (Walter and Dohse, 2012). This 
can inspire her to embark on entrepreneurial endeavors without adequate entrepreneurship education. Here, the societal environment serves as an alternative source of image-driven motivation to engage in entrepreneurial behavior. This is less likely in countries, in which skepticism towards entrepreneurship prevails and makes entrepreneurship education a more critical source of entrepreneurial motivation. For instance, Souitaris et al. (2007) found that taking entrepreneurship courses can shape subjective norms.

Further, anti-entrepreneurial attitudes in a country complicate entrepreneurial activity, and hence individuals require better education to perceive and derive utility from it. If the public image of entrepreneurs in a country is negatively biased, the utility arising from entrepreneurial activity may often be underestimated and underrated (Anokhin and Schulze, 2009). Entrepreneurship education sheds a more realistic light on entrepreneurship, in terms of potential income, risks, and working conditions (Oosterbeek et al., 2010). This can lead an individual to appreciate an entrepreneurial career more and to believe more in her ability to overcome barriers, such as those resulting from the public’s reservations concerning entrepreneurship. Thus, ceteris paribus, the effect of entrepreneurship education on entrepreneurial activity may become stronger, the more negative the public image of entrepreneurs in a country:

Hypothesis 5. The public image of entrepreneurs negatively moderates the positive relationship between entrepreneurship education and entrepreneurial activity.

\section{Methods}

\subsection{Sample and data sources}

Individual-level data came from the Flash Eurobarometer (EB) Survey on Entrepreneurship No. 283 (cf. Block et al., 2013). The survey is representative of the general population (in China: urban population) aged 15 years and above (Gallup Organization, 2010) 
and covers 36 countries: 27 EU states, five other European countries (Croatia, Iceland, Norway, Switzerland, and Turkey) and China, Japan, South Korea, and the United States. A total of 26,168 respondents aged 15 years and older were interviewed, primarily via phone, between December 2009 and January 2010. In nine countries (Bulgaria, the Czech Republic, Estonia, Hungary, Latvia, Lithuania, Poland, Romania, and Slovakia), the interviews were conducted face-to-face, accounting for approximately $30 \%$ of the total number of interviews. The target sample size was 1,000 respondents in 16 countries (Belgium, China, the Czech Republic, Germany, Greece, France, Hungary, Italy, Japan, the Netherlands, Poland, Portugal, South Korea, Spain, the United Kingdom, and the United States) and 500 respondents in the remaining countries.

Of the 26,168 respondents, 12,236 were of working age (15 to 65 years old) and either self- or wage-employed at the time of the survey. We excluded four countries (Malta, Portugal, Slovakia, and Turkey, altogether 1006 cases), for which ‘entrepreneurship education’ showed weak measurement model fit (as explained below). This led to our final sample of 11,230 individuals from 32 countries. The average respondent was 44 years old (sd $=10.96)$ and has finished full-time education at the age of $20(s d=3.23)$. Our sample profile is similar to that of the widely used Global Entrepreneurship Monitor (e.g., Aidis et al., 2008; Anokhin and Schulze, 2009; McMullen et al., 2008; Urbano and Alvarez, 2014). ${ }^{10}$

Country-level data came from various, commonly-accepted sources, including the Educational Attainment Dataset (Barro and Lee, 2013), the Doing Business Database (World Bank, 2011a), the Global Competitiveness Report (World Economic Forum, 2010), the World Competitiveness Yearbook (Institute for Management Development, 2011), and the World Governance Indicators (World Bank, 2011b). To avoid bias due to extreme observations, e.g.,

\footnotetext{
${ }^{10}$ Applying our sampling criteria, the two datasets had 24 countries in common. These samples were similar regarding self-employment (Flash EB: 20\%, GEM: 17\%) and age (Flash EB: mean = 43.97, sd = 11.01; GEM: mean $=42.62$, $s d=10.92$ ) but differed regarding the share of male respondents (Flash EB: 48\% male, GEM: $59 \%$ male).
} 
recession periods, we used a 7-year average (2004-2010) where possible. Table 1 summarizes key characteristics of our sample.

Please insert Table 1 about here

\subsection{Measures}

\subsubsection{Dependent variable}

The Flash EB survey operationalized entrepreneurial activity through one question: “As far as your current occupation is concerned, would you say you are self-employed, in paid employment or would you say you are without a professional activity?” Three response categories were possible, including "self-employed” (e.g., architects and owner-managers of a company), “in paid employment”, and "without a professional activity” (i.e., students, retired individuals, and the unemployed). Given the focus of our study, we excluded observations from the latter category from our analysis. Responses were coded 1 for entrepreneurial activity, i.e., being self-employed, and 0 for being wage-employed at the time of the survey.

\subsubsection{Independent variables}

Entrepreneurship education was measured with four items on a 4-point Likert-Scale (1 = "strongly agree”, 4 = "strongly disagree"; reversed scale): "My school education helped me develop my sense of initiative—a sort of entrepreneurial attitude”, "My school education helped me to better understand the role of entrepreneurs in society.”, "My school education made me interested to become an entrepreneur", and "My school education gave me skills and know-how that enable me to run a business" $(\alpha=0.81)$. This measure furthers our study by highlighting the extent to which entrepreneurship education has led individuals to generally perceive entrepreneurial activity to be more desirable and feasible-aspects that are central to the model of entrepreneurial action. In comparison, previous studies have adopted a more 
disaggregated view: They measured participation in entrepreneurship courses or the extent to which such courses are offered in curricula and then hypothesized that this should enhance perceptions of desirability, feasibility, or related constructs (e.g., Souitaris et al., 2007; Walter and Dohse, 2012).

Having a multiple-item construct allowed us to test for measurement invariance. Although this practice is not widespread, failure to establish measurement equivalence in cross-country research can induce measurement error, bias estimators and reduce the power of statistical tests (Diamantopoulos and Papadopoulos, 2010). We began testing measurement model fit through country-wise confirmatory factor analyses. Four countries, Malta, Portugal, Slovakia, and Turkey, presented insufficient fit $(G F I s<0.80)$ and were thus excluded from further analyses. However, robustness checks confirmed that our main findings are stable to including these countries. We then tested for measurement invariance as recommended by Vandenberg and Lance (2000; Table 2). The covariance matrices were not equal across countries and thus some form of measurement inequivalence exists (Test 1). However, the a priori pattern of free and fixed loadings imposed on the items was invariant across countries (Test 2, configural invariance), and the factor loadings of like items were equal across countries (Test 3, metric invariance). The final test indicated that the vector of item intercepts varied across countries and could therefore not confirm scalar invariance. As Vandenberg and Lance (2000) note, this does not necessarily suggest bias, but is often caused by the context of a study. ${ }^{11}$ In our case, differences in intercepts may reflect country differences in the extent to which entrepreneurship education is emphasized (EACEA, 2012) and considered good preparation for the country-typical form of entrepreneurship. Moreover, after freeing Items 1 and 4, at least partial scalar invariance was confirmed. Overall, our findings of configural,

\footnotetext{
${ }^{11}$ Vandenberg and Lance (2000: 38) note, “intercept differences may not reflect biases (undesirable) but response threshold differences that might be predicted based on known group differences (desirable), for example, between inexperienced versus highly experienced employees. Thus, whether this invariance test should be undertaken depends greatly on the substantive context underlying the study."
} 
metric, and partial scalar invariance strengthen our belief that measurement inequality does not distort our analysis.

Please insert Table 2 about here

Institutional variables were constructed, unless stated otherwise, as an average over the years 2004 to 2010. Entrepreneur-friendly regulations were measured by a composite of three different aspects. The first aspect, start-up regulations, i.e., legal provisions allowing one to start a business in a quick and cost-efficient manner (Stel et al., 2007), was captured by three standardized items taken from the Doing Business Database (World Bank, 2011a). The respective items reflect the regulatory burden associated with starting a business, including (1) the number of procedures, i.e., interactions with external parties such as government agencies, (2) the number of calendar days, as evaluated by incorporation lawyers, and (3) the costs, such as fees and notary charges, as a percentage of per capita income necessary to obtain legal status. Since we are interested in 'entrepreneur-friendly' regulations, the signs of the items were inverted $(\alpha=0.79)$. The second aspect is bankruptcy regulations, i.e., legal provisions allowing one to file bankruptcy in a quick and cost-efficient manner. Similar to Lee et al. (2011), our measure comprises three standardized items from the Doing Business Database, including (1) the time in calendar years required to recover debt, (2) costs as a percentage of the debtor's estate value to recover debt, and (3) the recovery rate, in cents on the dollar, available to creditors through reorganization, liquidation or debt enforcement. Items 1 and 2 received negative signs to reflect entrepreneur-friendly regulations $(\alpha=0.79)$. The final aspect was intellectual property rights, i.e., the degree to which rights to intellectual property are granted and enforced, for which we used a measure provided by the World Competitiveness Yearbook (Institute for Management Development, 2011). A sample of executives (representative of the economic sectors in a country, namely, primary, manufacturing, and 
services) rated the degree to which intellectual property rights are adequately enforced in their country (10-point Likert-scale, 0 = “are not adequately enforced”, 10 = "are adequately enforced"). The three aspects were standardized and summed to yield our final measure of entrepreneur-friendly regulations.

Financial capital availability was measured using data provided by the Global Competitiveness Report (World Economic Forum, 2010), in particular three items that are also employed by De Clerq et al. (2013). On average, 100 experts per country evaluated the ease of obtaining funding in their country (7-point Likert-scale, 1 = "very difficult", 7 = "very easy”). This includes access to the stock market ("How easy is it to raise money by issuing shares on the stock market in your country?”), access to venture capital (“In your country, how easy is it for entrepreneurs with innovative but risky projects to find venture capital?”), and access to bank loans ("How easy is it to obtain a bank loan in your country with only a good business plan and no collateral?”; $\alpha=0.91$ ). Similar to Lim et al. (2010), we measured educational capital availability as the average years of schooling for the total population, as provided by the Educational Attainment Dataset (Barro and Lee, 2013).

Our measure for control of corruption is one of the six widely used World Governance Indicators (World Bank, 2011b). The particular indicator used in our study has the widest coverage of all corruption indices (Anokhin and Schulze, 2009) and reflects perceptions of the extent to which public power is exercised for private gain, including both petty and grand forms of corruption. The measure gathers various information, such as respondents’ perception of the level of "unofficial payments to public officials" and corruption by elected leaders. It reflects the perceived quality of governance, in terms of addressing corruption, and ranges from approximately -2.5 (weak governance) to 2.5 (strong governance). Finally, the Flash Eurobarometer No 208 contains one question concerning the public image of entrepreneurs ("What is your opinion about the following groups of persons?”; 3-point Likert-scale, 1 = "rather favorable”, 3 = "rather unfavorable”). To construct our measure, we 
calculated the share of persons in a country with a favorable opinion of entrepreneurs, with a low of 0.29 in Hungary and a high of 0.86 in Iceland. This aggregation was based on the complete dataset of 26,168 respondents, not only our subset of 11,230 self- and wageemployed respondents.

\subsubsection{Control variables}

To isolate the effect of our independent variables, various control variables were included in our regressions. At the individual level, we controlled for the age of the respondent because the opportunity costs of entrepreneurship increase with age (Lévesque and Minniti, 2006), making older individuals less likely to engage in entrepreneurial activity. Men were found to start new ventures more often than women (Brush, 1992). Gender effects were captured with a dummy variable for being male $(1=$ male, $0=$ female). Investments in human capital can enhance the payoffs from entrepreneurship (Unger et al., 2011). We therefore controlled for the respondent's education level, i.e., the age when finishing full-time education minus the usual age of starting education, namely six years. Self-employed kin can serve as role models (Scherer et al., 1989) and a source of entrepreneurial know-how (Tervo, 2006). We included two separate dummy variables for having a self-employed father and/or a self-employed mother $(1=$ self-employed, 0 = otherwise $)$.

Various personality traits were found to promote entrepreneurial activity (Rauch and Frese, 2007). Entrepreneurs are believed to accept more risks than others as they are confronted with less structured and more uncertain problems and bear the ultimate responsibility for their decisions (Stewart Jr. and Roth, 2001). Risk tolerance was captured with the item "In general, I am willing to take risks" on-as is the case for the subsequent variables—a 4-point Likert-scale (1 = “strongly agree” to 4 = "strongly disagree”; scale

reversed). To persevere in the face of uncertainty, entrepreneurs need high self-confidence (Wilson et al., 2007), which was measured by the item "Generally, when facing difficult 
tasks, I am certain that I will accomplish them”. Feeling able to control outcomes can give individuals the necessary drive to successfully start a new venture. Internal locus of control was measured with the item "My life is determined by my own action, not by others or by chance”. Creativity facilitates the discovery of entrepreneurial opportunities (Lee and Wong, 2004), which is a prerequisite for entrepreneurship. Inventiveness was measured with the item "I am an inventive person who has ideas”. Achievement-oriented individuals prefer entrepreneurial careers as they permit direct feedback on own performance (Collins et al., 2004). This was considered with one item for the desire for competition ("I like situations in which I compete with others”). Proactivity facilitates the perception of opportunities and acting on them (Crant, 1996). It was measured with the item "If I see something I do not like, I change it”. Optimism leads individuals to view the challenges of entrepreneurship more positively (Rauch and Frese, 2007) and was captured through the item "I am optimistic about my future". At the country level, we controlled for differences in national wealth in terms of GDP per capita at purchasing power parity (international dollars) averaged over the years 2004 to 2010. Data came from the Global Competitiveness Report (World Economic Forum, 2010).

\subsection{Analysis}

\subsubsection{Hierarchical linear modeling}

Traditional methods to analyze nested data pose threats of aggregation or disaggregation bias. We thus employed hierarchical linear modeling (HLM; Raudenbush and Bryk, 2002) with restricted maximum likelihood estimates to test our cross-level hypotheses. HLM examines each variable at its natural level and considers partial interdependence between individuals in the same country. HLM tends to provide parameter estimates similar to those of an Ordinary Least Squares (OLS) regression, but mitigates the deflation in standard errors associated with OLS for nested data. Since our hypotheses postulated moderating effects of 
country-level variables (institutions) on individual-level relationships (entrepreneurship education and entrepreneurial activity), we employed slopes-as-outcomes models. We meancentered metric predictors to make the intercept more interpretable. However, we obtained the same pattern of results when using raw data. Specifically, we accounted for the Bernoulli distribution of our dependent variable by using hierarchical generalized linear models (HGLM). Similar to normal logistic regression, the individual-level estimates do not refer to levels of the dependent variable but to the natural logarithm of the likelihood (log-odds) that the dependent variable will take a value of 1 denoting being self-employed rather than a value of 0 denoting being wage-employed. However, the country-level estimates are interpreted similarly to those obtained from linear regressions because the intercepts and slopes from the individual-level model are continuous and normally distributed.

\subsubsection{Common method bias}

Collecting data for the dependent and independent variables from the same source can lead to common method bias. While combining survey data with archival data mitigates this risk (Podsakoff et al., 2003), we also conducted several ex-post tests for such a bias. First, we applied Harman’s one-factor test on all observed indicators. For no country did a single factor emerge that accounted for the majority of covariance between the indicators. Second, using the CFA marker technique (Williams et al., 2010)— to date, the most advanced ex-post statistical control strategy (Richardson et al., 2009)—we attempted to identify the existence and extent of common method effects by comparing a baseline model with three other models: The 'Method-C model' assumes equal method effects, the 'Method-U model' assumes unequal methods effects, and the 'Method-R model' is identical to the Method-C and U models, except that it constrains the factor correlations to the values from the baseline model. A measure of attitudes toward civil servants (3-point Likert-scale; 1 = "rather favorable”, 3 = "rather unfavorable”) served as our theoretically unrelated marker variable. In 
26 countries, method factor loadings (assumed to be equal) were not significantly related to substantive indicators (Baseline vs. Method-C models, $\Delta \chi^{2}<3.59, \Delta d f=1, n s$ ). For 13 countries, the tests suggested that the marker variable had an unequal impact on the substantive indicators (Method-C vs. Method-U models, $\Delta \chi^{2}>19.68, \Delta d f=11, p<.05$ ). However, further tests indicated that the equal or unequal effects of the marker variable did not significantly bias the estimates of substantive factor correlations (Method-C vs. Method-R models, $\Delta \chi^{2}<15.81, \Delta d f=25$, $n s$; Method-U vs. Method-R models, $\Delta \chi^{2}<4.92, \Delta d f=36, n s$ ). According to these tests, common method bias did not pose a serious threat to the validity of our main results.

\subsubsection{Endogeneity}

Perceptions of entrepreneurship education drive, as we argue, entrepreneurial activity but also a reverse logic is possible: entrepreneurial activity influences perceptions of entrepreneurship education, for instance due to ex-post rationalization or socially desirable answers by the respondents. Simultaneous causality is one source of endogeneity that can lead to biased and inconsistent coefficients. Two-stage instrumental variables regression can mitigate endogeneity-related bias but at the cost of producing much larger standard errors than standard regression. It is therefore recommendable, even if a variable appears theoretically endogenous, not to model it as endogenous until tests confirm that endogeneity is a statistical problem (Wooldridge, 2003). Two instrument variables, namely (1) opinions concerning topmanagers in large production companies and (2) opinions concerning managers in a bank or a similar institution, were significantly correlated with the potentially endogenous variable (entrepreneurship education), but not with the dependent variable (entrepreneurial activity), and were significantly related to entrepreneurship education in the first-stage regression. Tests suggested that the instruments were relevant $(F=60.72, p<.001$; Staiger and Stock, 1997) and exogenous (Amemiya-Lee-Newey statistic $=.09, n s$ ). Using these instruments, we find 
that endogeneity does not pose a serious problem: Both a Wald test on exogeneity $\left(X^{2}=.01\right.$, $n s$ ) and a weak-instrument robust test (Anderson-Rubin statistic: $X^{2}=.37, n s$ ) could not reject the null hypothesis that entrepreneurship education is exogenous.

\section{Results}

\subsection{Main results}

Table 3 depicts the descriptive statistics and correlation matrix. Table 4 describes the regression results. Computations of the condition index $(\mathrm{CI})$ and variance inflation factor (VIF) indicate no serious multicollinearity problems $(C I<3.13, V I F<2.24)$. The models explained between 11.08\% (Model 1) and 14.39\% (Model 10) of the variation in entrepreneurial activity (Snijders and Bosker, 1999: 255-257). ${ }^{12}$

Please insert Tables 3 and 4 about here

Our five hypotheses posited that the positive relationship between entrepreneurship education and entrepreneurial activity is negatively moderated by country-level institutions, or in other words, that the relationship is stronger in entrepreneurship-hostile institutional environments than in entrepreneurship-friendly environments. The regression results support Hypothesis 1 regarding entrepreneur-friendly regulations (Model 4: $b=-.04, p<.01$ ), Hypothesis 2 regarding financial capital availability (Model 6: $b=-.14, p<.05$ ), Hypothesis 4 regarding control of corruption (Model 10: $b=-.11, p<.05$ ), and Hypothesis 5 regarding the public image of entrepreneurs (Model 12: $b=-.53, p<.01$ ). However, we found no support for Hypothesis 3 regarding educational capital availability (Model 8: $b=.01, n s$ )

\footnotetext{
${ }^{12}$ Many authors employing HLM are cautious to avoid overburdening models and creating artifacts (e.g., Cullen et al., 2014; De Clercq et al., 2013; Martin et al., 2007). Similarly, we tested cross-level interactions one at a time rather than in a full model because our institutional variables were highly correlated and the degrees of freedom at country level relatively small (12 country-level variables and 32 countries).
} 
Since the sign and magnitude of interactions can vary across observations in non-linear regressions, the estimated coefficient alone is insufficient to draw conclusions regarding an interaction’s sign and significance (Hoetker, 2007). We therefore graphed the interaction effects according to a procedure developed by Norton et al. (2004; implemented in STATA's 'inteff' command). The procedure considers that in non-linear regressions the interaction effect is a function of the interaction coefficient and — unlike in OLS regression—of the coefficient of each interacted variable and of the values of all covariates (Hoetker, 2007). Inspection of the plots (available from the first author) suggested that the four moderating effects were negative and significant almost over the whole range of predicted values for entrepreneurial activity. For ease of presentation, Figure 1 displays simplified plots according to Jaccard (2001). The graphs involve computing four point estimates of the probability of entrepreneurial activity using the means of the covariates and four combinations of high and low entrepreneurship education and the respective institutional variable (mean +/- one standard deviation). Overall, the plots further support Hypotheses 1, 2, 4, and 5.

Please insert Fig. 1 about here

\subsection{Additional analyses}

We conducted several robustness checks. These findings are omitted here for space reasons but are available from the first author. First, additional influences at the country level, including the age structure of the population, business friendliness, democracy before 1960, emerging economies, former Eastern Bloc country, immigrant share, taxation, service orientation, and unemployment rate can explain country differences in entrepreneurial activity (De Clercq et al., 2013, Bowen and De Clercq, 2008; Lee et al., 2011). However, adding these control variables to our models one after another did not change the pattern of our main findings. Second, the literature has suggested culture as an important aspect of a cross- 
national understanding of entrepreneurship (e.g., Hayton and Cacciotti, 2013). In an approach similar to Cullen et al. (2014), we reran our regressions testing cultural dimensions (Hofstede, 1980; House et al., 2004) as moderators, one at a time. Only institutional collectivism (values) had a significant positive moderating effect on outcomes of entrepreneurship education. Moreover, our main results were stable to controlling for cultural dimensions. ${ }^{13}$ Third, we reran our regressions with country-level variables based on data long before 2004, including control of corruption (1996-2010), immigrant share and service orientation (1960-2010). The findings based on the long-term variants of the variables did not differ significantly from our original results. Fourth, we aggregated our institutional variables into one composite measure that significantly and negatively moderated the relationship between entrepreneurship education and entrepreneurial activity. Fifth, our original results remained virtually unchanged when controlling for entrepreneurship experience. Sixth, our findings were also robust to expanding the sample to previously self- and wage-employed individuals who were without professional activity at the time of the survey. Seventh, one item of entrepreneurship ("My school education made me interested to become an entrepreneur") could be tautological to entrepreneurial activity. Our results remain virtually unchanged when removing this item. Finally, we added 1,088 unemployed respondents to the sample and estimated hierarchical multinomial logistic models. The findings confirm our original results.

\section{Discussion and implications}

Many countries have allocated considerable resources to establish entrepreneurship education at universities, high schools, and primary schools. However, empirical evidence on the returns on these investments, in terms of creating interest in an entrepreneurial career and thus more entrepreneurial activity, has been mixed. From a practical perspective, this is a problematic situation for policy-makers and educators, who face increasing expectations to

\footnotetext{
${ }^{13}$ Correlations of our institutional variables with cultural dimensions (practices) ranged from $r=-.53$ for power distance and financial capital availability to $r=.40$ for uncertainty avoidance and control of corruption.
} 
justify educational investments and to rank educational outcomes internationally. From a theoretical perspective, the mixed findings can reflect what scholars have long proposed, namely that entrepreneurship is triggered by a person-context interaction (e.g., Learned, 1992) and that moderating influences might explain some of the variance in prior findings (e.g., Bae et al., 2014; Martin et al., 2013). Our study furthers research on contextual contingencies of entrepreneurship education by arguing that a country's institutional environment matters for the outcomes of entrepreneurship education. Specifically, we posit that entrepreneurship education is more effective, in terms of stimulating more entrepreneurial activity, in entrepreneurship-hostile institutional environments, thus in those countries low in entrepreneur-friendly regulations (Hypothesis 1), financial capital availability (Hypothesis 2), educational capital availability (Hypothesis 3), control of corruption (Hypothesis 4) and public image of entrepreneurs (Hypothesis 5). Our empirical results support these arguments in all but one case: The strength of the individual-level relationship between entrepreneurship education and entrepreneurial activity varied systematically with country-level institutional variables (except for educational capital availability), being stronger in countries with entrepreneurship-hostile institutions.

Two findings warrant further discussion. First, our results could not confirm a significant moderating effect of educational capital availability (Hypothesis 3). One explanation could be that much of the entrepreneurial activity in countries with underdeveloped, entrepreneurship-hostile institutions is likely to be necessity driven (Reynolds et al., 2003: 20). Since this type of start-up tends to grow slowly, if at all, human resources are a less critical factor. For instance, Stel et al. (2007) report that rigid employment regulations are negatively related to the rate of opportunity-driven, but unrelated to necessitydriven nascent entrepreneurship. Moreover, a countervailing effect could neutralize our hypothesized effect: If critical human resources are scarce, a potential entrepreneur might decide against engaging in entrepreneurial activity despite having had excellent 
entrepreneurship education. Second, entrepreneur-friendly regulations and control of corruption were significantly negatively related to entrepreneurial activity, which is contrary to our expectations that they would create a context conducive to entrepreneurship. One potential explanation is that corruption might create entrepreneurial opportunities in some countries. Welter and Smallbone (2011) offer the example of management consultancy firms helping to obtain business licenses and permits in highly corrupt countries. Another explanation is that entrepreneur-friendly regulations and control of corruption are characteristics of well-developed countries, as indicated by their high correlation with GDP per capita, and that the rate of new firm entry tends to decline in well-developed countries, as indicated by the negative correlation between GDP per capita and entrepreneurial activity.

\subsection{Implications for research}

This study offers several implications for related research. First, our findings add to a broad stream of literature on the outcomes of entrepreneurship education. Prior research relied on single-country data to link entrepreneurship education to entrepreneurial intentions (e.g., Peterman and Kennedy, 2003; Walter et al., 2013). In particular quasi-experimental studiesthe dominant type of studies in the field-had to disregard contextual influences as a matter of design (e.g., Souitaris et al., 2007). However, meta-analyses on educational outcomes have led to speculation concerning the existence of moderating influences (Bae et al., 2014; Martin

et al., 2013; Unger et al., 2011). Our study contributes to this line of research by adopting, theoretically and empirically, a cross-country, multilevel perspective to show that outcomes of entrepreneurship education are contingent on a country's institutional environment. This complements prior research focusing on entrepreneurship-specific human capital (De Clercq et al., 2013) or the regional context (Walter and Dohse, 2012). Moreover, much prior work has explored effects directly after taking entrepreneurship courses, in particular possibly short-lived entrepreneurial intentions (e.g., Peterman and Kennedy, 2003; Souitaris et al., 
2007). Our study emphasizes the long-lasting effects of entrepreneurship education by examining entrepreneurial activity.

Second, theorizing on entrepreneurship education has typically focused on the individual level (e.g., Souitaris et al., 2007). However, understanding the value of such education may require considering multiple levels of analysis and including contextual influences. Following calls for more multilevel theory building in entrepreneurship research (Shepherd, 2011), our study combined logic from institutional theory at the macro level and the model of entrepreneurial action at the micro level. According to our theory, the institutional environment alters individual utility functions related to entrepreneurship and can substitute for entrepreneurship education as a source of entrepreneurial knowledge and inspiration. This has implications for studies on the outcomes of entrepreneurship education, with their focus on individual-level theory, such as the theory of planned behavior (Ajzen, 1991) or Shapero's model of the entrepreneurial event (Krueger et al., 2000). These theories propose behavioral intentions as the best indicator of actual entrepreneurial behavior (Armitage and Conner, 2001). Our study suggests that the intention-behavior link might be conditioned by the institutional context (cf. Schlaegel and Koenig, 2014). In other words, the ‘conversion rate’ of entrepreneurship education, i.e., the share of entrepreneurship students subsequently becoming entrepreneurs, might be contingent on institutions. In entrepreneurship-hostile institutions, more students who are inspired and prepared by entrepreneurship education actually choose entrepreneurial careers, whereas in entrepreneurship-friendly institutions, they are more inclined to opt for entrepreneurshiprelated occupations, e.g., working as an intrapreneur in an established firm.

Finally, this article contributes to the growing literature on institutional theory and entrepreneurship. Recently, scholars have begun to adopt institutional theory to illuminate how a country's institutional profile directly affects the allocation of entrepreneurial activity (e.g., Anokhin and Schulze, 2009; Bowen and De Clercq, 2008). Some studies challenged the 
notion that highly developed institutions such as strong legal protection are conducive to entrepreneurial activity (Kim and Li, 2014). Our study demonstrated the contingent role of institutions in the context of entrepreneurship education. This finding suggests (similar to De

Clercq et al., 2013) that research should be extended to include both the direct and moderating effects of institutions in other contexts. Considering both possibilities not only promises fresh insights, but it may also help to better exploit the explanatory potential of institutional theory (North, 1990; Whitley, 1999). Moreover, institutional theory has acknowledged educational organizations as drivers of change that contribute to a country's economic performance by creating and disseminating knowledge that can alter the institutional framework (North, 1990: 79-80). Our results concerning the moderating effect of the public image of entrepreneurs support this notion: Individuals with a positive impression of their entrepreneurship education are more likely to become entrepreneurs in countries with a negative opinion towards entrepreneurs. This allows speculations that educational institutions such as schools or universities could generate an entrepreneurship-friendly climate even in relatively entrepreneurship-hostile environments and could thereby act as 'change agents' to create more entrepreneurship in a society.

\subsection{Practical implications}

Countries increasingly benchmark educational outcomes, as exemplified by the PISA studies (OECD, 2013). At least implicitly, many intention-based studies suggest the relative number of start-ups resulting from entrepreneurship education as an indicator of its quality. Our study cautions against using start-up numbers alone to compare entrepreneurship education quality across countries because these numbers are conditioned by the national institutional context and could thus be ‘biased’. Moreover, many entrepreneurship syllabi appear designed to suit needs of future entrepreneurs. However, our theory indicates that in entrepreneurship-friendly institutional environments, existing companies and organizations 
absorb some extent of the entrepreneurial potential created at schools and universities. This suggests extending entrepreneurship syllabi by inclusion of topics such as corporate entrepreneurship or entrepreneurship support schemes. Finally, our finding that entrepreneurship education has a particularly strong effect in entrepreneurship-hostile environments serves as a motivation for policy-makers to promote entrepreneurship education in such countries.

\subsection{Limitations and further research}

This study is not without limitations that mark potential avenues for further research. First, the Flash Eurobarometer database lacks information on firm characteristics, such as industry, size, growth, and financial performance, which precluded considering firm heterogeneity in our analyses. Although we suspect that much entrepreneurship in entrepreneurship-hostile institutional environments consists of micro businesses, the data restrictions do not allow any conclusions on the economic relevance of the observed entrepreneurial activity. Future research could therefore explore how the interplay of entrepreneurship education and country-level institutional context shapes the success and evolution of start-ups (e.g., Estrin et al., 2013). For instance, positive moderation effects could be expected for financial capital availability, a key constraint on start-up growth (Carpenter and Petersen, 2002). Second, data limitations precluded more nuanced tests regarding serial and hybrid entrepreneurship. Third, our sample primarily comprises European countries, but also China, Japan, South Korea and the U.S., and hence our results are conditional and mostly generalizable to that national context. Since the database excluded many developing countries outside Europe, other samples are more suitable to examine how entrepreneurship education contributes to entrepreneurial activity in these countries. Fourth, the Flash Eurobarometer survey measured psychological traits with single items. Although single-item measures were found to have acceptable estimated reliability (Wanous and Reichers, 1996) and predictive 
validity similar to multi-item measures (Bergkvist and Rossiter, 2007), the findings for these variables should be interpreted with caution.

Fifth, data limitations precluded controlling for migration effects. Immigrants might face entry barriers to the labor market and adhere to a value system that differs from a country's informal institutions. Some immigrants might have attended school and started their business in different countries. While our theory makes no assumptions regarding the origin of entrepreneurship education, this raises interesting questions for future research. For instance, to what extent is the content of entrepreneurship education country-specific? Is motivation and knowledge gained via such education, in particular at school, equally valuable in another country setting? Sixth, studying entrepreneurship education retrospectively might have left some potential for recall bias. To minimize this risk, we controlled for variables, such as the respondent's age and education level, that can explain systematic variation in such bias across respondents (Cassar, 2014). Moreover, additional analyses suggested that the effect sizes of entrepreneurship education do not significantly vary with the time lag between the start of a business and the timing of the survey. Thus, the risk of recall bias seems to be low, although we cannot completely rule out this possibility. Seventh, the high correlations among institutional variables precluded testing a comprehensive model including all institutional variables. This raises another interesting question for future research, namely whether and when institutions in a country converge to a consistent framework. Eighth, previous studies measured entrepreneurship education in terms of taking entrepreneurship courses (e.g., Gielnik et al., 2015; Souitaris et al., 2007), whereas our study adopted a perceptual measure. These differences might affect the comparability of the respective findings. Finally, since this study focused on five institutional variables drawn from Whitley's (1999) framework, future research could corroborate our findings by testing other institutions and frameworks (e.g., Scott, 1995). 


\section{Conclusion}

Contributing to an institutional view of entrepreneurship education, we have mapped out how entrepreneurship education is more likely to result in entrepreneurial activity in entrepreneurship-hostile country environments. Being aware of institutional contingencies helps policy makers and educators more closely align entrepreneurship education to the specific country context and evaluate its outcomes in a context-dependent way. Entrepreneurship researchers can use the institutional lens to leave the confined space of single-level models to theorize on outcomes of entrepreneurship education from a cross-level perspective.

\section{References}

Aidis, R., Estrin, S., Mickiewicz, T. 2008. Institutions and entrepreneurship development in russia: A comparative perspective. Journal of Business Venturing 23(6): 656-672.

Ajzen, I. 1991. The theory of planned behavior. Organizational Behavior and Human Decision Processes 50(2): 179-211.

Anokhin, S., Schulze, W.S. 2009. Entrepreneurship, innovation, and corruption. Journal of Business Venturing 24(5): 465-476.

Armitage, C.J., Conner, M. 2001. Efficacy of the theory of planned behaviour: A meta-analytic review. British Journal of Social Psychology 40(4): 471-499.

Armstrong, P.I., Crombie, G. 2000. Compromises in adolescents' occupational aspirations and expectations from grades 8 to 10. Journal of Vocational Behavior 56(1): 82-98.

Athayde, R. 2009. Measuring enterprise potential in young people. Entrepreneurship: Theory \& Practice 33(2): 481-500.

Autio, E., Acs, Z. 2010. Intellectual property protection and the formation of entrepreneurial growth aspirations. Strategic Entrepreneurship Journal 4(3): 234-251.

Bae, T.J., Qian, S., Miao, C., Fiet, J.O. 2014. The relationship between entrepreneurship education and entrepreneurial intentions: A meta-analytic review. Entrepreneurship Theory and Practice 38(2): 217-254.

Baker, T., Gedajlovic, E., Lubatkin, M. 2005. A framework for comparing entrepreneurship processes across nations. Journal of International Business Studies 36(5): 492-504.

Barro, R.J., Lee, J.W. 2013. A new data set of educational attainment in the world, 1950-2010. Journal of Development Economics 104(1): 184-198.

Baumol, W.J. 1990. Entrepreneurship: Productive, unproductive, and destructive. Journal of Political Economy 98(5): 893-921.

Begley, T.M., Tan, W.L., Schoch, H. 2005. Politico-economic factors associated with interest in starting a business: A multi-country study. Entrepreneurship Theory and Practice 29(1): 35-55. 
Bergkvist, L., Rossiter, J.R. 2007. The predictive validity of multiple-item versus single-item measures of the same constructs. Journal of Marketing Research 44(2): 175-184.

Block, J., Thurik, R., van der Zwan, P., Walter, S. 2013. Business takeover or new venture? Individual and environmental determinants from a cross-country study. Entrepreneurship Theory and Practice 37(5): 10991121.

Bowen, H.P., De Clercq, D. 2008. Institutional context and the allocation of entrepreneurial effort. Journal of International Business Studies 39(4): 747-767.

Brush, C.G. 1992. Research on women business owners: Past trends, a new perspective and future directions. Entrepreneurship Theory \& Practice 16(4): 5-30.

Brush, C.G., Duhaime, I.M., Gartner, W.B., Stewart, A., Katz, J.A., Hitt, M.A., Alvarez, S.A., Meyer, G.D., Venkataraman, S. 2003. Doctoral education in the field of entrepreneurship. Journal of Management 29(3): 309331.

Bruton, G.D., Ahlstrom, D., Li, H.-L. 2010. Institutional theory and entrepreneurship: Where are we now and where do we need to move in the future? Entrepreneurship Theory and Practice 34(3): 421-440.

Busenitz, L.W., Gomez, C., Spencer, J.W. 2000. Country institutional profiles: Unlocking entrepreneurial phenomena. Academy of Management Journal 43(5): 993-1003.

Carpenter, R.E., Petersen, B.C. 2002. Is the growth of small firms constrained by internal finance? Review of Economics and Statistics 84(2): 298-309.

Cassar, G. 2014. Industry and startup experience on entrepreneur forecast performance in new firms. Journal of Business Venturing 29(1): 137-151.

Collins, C.J., Hanges, P.J., Locke, E.A. 2004. The relationship of achievement motivation to entrepreneurial behavior: A meta-analysis. Human Performance 17(1): 95-117.

Covin, J.G., Miles, M.P. 2007. Strategic use of corporate venturing. Entrepreneurship: Theory \& Practice 31(2): 183-207.

Crant, J.M. 1996. The proactive personality scale as a predictor of entrepreneurial intentions. Journal of Small Business Management 34(3): 42-49.

Cullen, J.B., Johnson, J.L., Parboteeah, K.P. 2014. National rates of opportunity entrepreneurship activity: Insights from institutional anomie theory. Entrepreneurship: Theory \& Practice 38(4): 775-806.

Cunha, F., Heckman, J. 2007. The technology of skill formation. American Economic Review 97(2): 31-47.

De Clercq, D., Lim, D.S.K., Oh, C.H. 2013. Individual-level resources and new business activity: The contingent role of institutional context. Entrepreneurship Theory and Practice 37(2): 303-330.

Diamantopoulos, A., Papadopoulos, N. 2010. Assessing the cross-national invariance of formative measures: Guidelines for international business researchers. Journal of International Business Studies 41(2): 360-370.

Dickson, P.H., Solomon, G.T., Weaver, K.M. 2008. Entrepreneurial selection and success: Does education matter? Journal of Small Business and Enterprise Development 15(2): 239-258.

Douglas, E.J., Shepherd, D.A. 2002. Self-employment as a career choice: Attitudes, entrepreneurial intentions, and utility maximization. Entrepreneurship Theory \& Practice 26(3): 81-90.

EACEA 2012. Entrepreneurship education at school in europe: National strategies, curricula and learning outcomes. Education, Audiovisual and Culture Executive Agency, Brussels.

Ehrlich, I., Lui, F.T. 1999. Bureaucratic corruption and endogenous economic growth. Journal of Political Economy 107(6): 270-293. 
Eisenhauer, J.G. 1995. The entrepreneurial decision: Economic theory and empirical evidence. Entrepreneurship Theory \& Practice 19(4): 67-79.

Estrin, S., Korosteleva, J., Mickiewicz, T. 2013. Which institutions encourage entrepreneurial growth aspirations? Journal of Business Venturing 28(4): 564-580.

Evans, D.S., Jovanovic, B. 1989. An estimated model of entrepreneurial choice under liquidity constraints. Journal of Political Economy 97(4): 808-827.

Frese, M., Krauss, S.I., Keith, N., Escher, S., Grabarkiewicz, R., Luneng, S.T., Heers, C., Unger, J., Friedrich, C. 2007. Business owners' action planning and its relationship to business success in three african countries. Journal of Applied Psychology 92(6): 1481-1498.

Gallup Organization 2010. Flash eurobarometer 283 "entrepreneurship in the eu and beyond". http://ec.europa.eu/enterprise/policies/sme/facts-figures-analysis/eurobarometer/fl283_en.pdf, 2011-1224.

Gielnik, M., Frese, M., Kahara-Kawuki, A., Katono, I., Kyejjusa, S., Munene, J., Ngoma, M., Namatovu-Dawa, R., Nansubuga, F., Orobia, L., Oyugi, J., Sejjaaka, S., Sserwanga, A., Walter, T., Bischoff, K., Dlugosch, T. 2015. Action and action-regulation in entrepreneurship: Evaluating a student training for promoting entrepreneurship. Academy of Management Learning \& Education 14(1): 69-94.

Gohmann, S.F. 2012. Institutions, latent entrepreneurship, and self-employment: An international comparison. Entrepreneurship Theory and Practice 36(2): 295-321.

Gorman, G., Hanlon, D., King, W. 1997. Some research perspectives on entrepreneurship education. International Small Business Journal 15(3): 56-77.

Hayton, J.C., Cacciotti, G. 2013. Is there an entrepreneurial culture? A review of empirical research. Entrepreneurship \& Regional Development 25(9/10): 708-731.

Hoetker, G. 2007. The use of logit and probit models in strategic management research: Critical issues. Strategic Management Journal 28(4): 331-343.

Hofstede, G. 1980. Culture's consequences: International differences in work related values. Sage, Beverly Hills, CA.

House, R.J., Hanges, P.J., Javidan, M., Dorfman, P.W., Gupta, V. 2004. Culture, leadership and organization: The globe study of 62 societies. Sage, Thousand Oaks, CA.

Huber, L.R., Sloof, R., Van Praag, M. 2014. The effect of early entrepreneurship education: Evidence from a field experiment. European Economic Review 72: 76-97.

Institute for Management Development 2011. World competitiveness yearbook, Lausanne.

Jaccard, J. 2001. Interaction effects in logistic regression. Sage, Thousand Oaks, CA.

Jennings, P.D., Greenwood, R., Lounsbury, M.D., Suddaby, R. 2013. Institutions, entrepreneurs, and communities: A special issue on entrepreneurship. Journal of Business Venturing 28(1): 1-9.

Katz, J.A. 2003. The chronology and intellectual trajectory of american entrepreneurship education 1876-1999. Journal of Business Venturing 18(2): 283-300.

Kautonen, T., van Gelderen, M., Fink, M. 2015. Robustness of the theory of planned behavior in predicting entrepreneurial intentions and actions. Entrepreneurship Theory and Practice 39(3): 655-674.

Kim, P.H., Li, M. 2014. Seeking assurances when taking action: Legal systems, social trust, and starting businesses in emerging economies. Organization Studies 35(3): 359-391.

Krueger, N.F., Reilly, M.D., Carsrud, A.L. 2000. Competing models of entrepreneurial intentions. Journal of Business Venturing 15(5/6): 411-432. 
Kulicke, M. 2014. 15 years of exist "university-based start-up programmes": Development of the exist funding programme between 1998 and 2013. Fraunhofer ISI, Karlsruhe.

Kumar, K.B., Rajan, R.G., Zingales, L. 1999. What determines firm size? National Bureau of Economic Research Working Paper Series No. 7208.

Kuratko, D.F., Morris, M.H., Covin, J.G. 2011. Corporate innovation \& entrepreneurship: Entrepreneurial development within organizations. South-Western Cengage Learning, Mason, $\mathrm{OH}$.

Learned, K.E. 1992. What happened before the organization? A model of organization formation. Entrepreneurship: Theory \& Practice 17(1): 39-48.

Lee, S.-H., Yamakawa, Y., Peng, M.W., Barney, J.B. 2011. How do bankruptcy laws affect entrepreneurship development around the world? Journal of Business Venturing 26(5): 505-520.

Lee, S.H., Wong, P.K. 2004. An exploratory study of technopreneurial intentions: A career anchor perspective. Journal of Business Venturing 19(1): 7-28.

Lévesque, M., Shepherd, D.A., Douglas, E.J. 2002. Employment or self-employment: A dynamic utilitymaximizing model. Journal of Business Venturing 17(3): 189-210.

Lévesque, M., Minniti, M. 2006. The effect of aging on entrepreneurial behavior. Journal of Business Venturing 21(2): 177-194.

Levie, J., Autio, E. 2011. Regulatory burden, rule of law, and entry of strategic entrepreneurs: An international panel study. Journal of Management Studies 48(6): 1392-1419.

Lim, D.S.K., Morse, E.A., Mitchell, R.K., Seawright, K.K. 2010. Institutional environment and entrepreneurial cognitions: A comparative business systems perspective. Entrepreneurship Theory and Practice 34(3): 491-516.

Martin, B.C., McNally, J.J., Kay, M.J. 2013. Examining the formation of human capital in entrepreneurship: A meta-analysis of entrepreneurship education outcomes. Journal of Business Venturing 28(2): 211-224.

Martin, K.D., Cullen, J.B., Johnson, J.L., Parboteeah, K.P. 2007. Deciding to bribe: A cross-level analysis of firm and home country influences on bribery activity. Academy of Management Journal 50(6): 1401-1422.

McMullen, J.S., Shepherd, D.A. 2006. Entrepreneurial action and the role of uncertainty in the theory of the entrepreneur. The Academy of Management Review 31(1): 132-152.

McMullen, J.S., Bagby, D.R., Palich, L.E. 2008. Economic freedom and the motivation to engage in entrepreneurial action. Entrepreneurship: Theory \& Practice 32(5): 875-895.

Meek, W.R., Pacheco, D.F., York, J.G. 2010. The impact of social norms on entrepreneurial action: Evidence from the environmental entrepreneurship context. Journal of Business Venturing 25(5): 493-509.

Millán, J.M., Congregado, E., Román, C., van Praag, M., van Stel, A. 2014. The value of an educated population for an individual's entrepreneurship success. Journal of Business Venturing 29(5): 612-632.

Minniti, M. 2008. The role of government policy on entrepreneurial activity: Productive, unproductive, or destructive? Entrepreneurship Theory \& Practice 32(5): 779-790.

Mueller, S.L., Thomas, A.S. 2001. Culture and entrepreneurial potential: A nine country study of locus of control and innovativeness. Journal of Business Venturing 16(1): 51-75.

North, D.C. 1990. Institutions, institutional change and economic performance. Cambridge University Press.

Norton, E.C., Wang, H., Ai, C. 2004. Computing interaction effects and standard errors in logit and probit models. The Stata Journal 4(2): 154-167.

OECD 2013. Pisa 2012 results in focus. http://www.oecd.org/pisa/keyfindings/pisa-2012-results-overview.pdf. 
Oosterbeek, H., van Praag, M., Ijsselstein, A. 2010. The impact of entrepreneurship education on entrepreneurship skills and motivation. European Economic Review 54(3): 442-454.

Patzelt, H., Williams, T.A., Shepherd, D.A. 2014. Overcoming the walls that constrain us: The role of entrepreneurship education programs in prison. Academy of Management Learning \& Education 13(4): 587-620.

Peng, M.W., Wang, D.Y., Jiang, Y. 2008. An institution-based view of international business strategy: A focus on emerging economies. Journal of International Business Studies 39(5): 920-936.

Peterman, N.E., Kennedy, J. 2003. Enterprise education: Influencing students' perceptions of entrepreneurship. Entrepreneurship Theory \& Practice 28(2): 129-144.

Petrou, A.P. 2014. Bank foreign affiliate performance in the face of pervasive and arbitrary corruption. European Management Review 11(3/4): 209-221.

Pittaway, L., Cope, J. 2007. Entrepreneurship education: A systematic review of the evidence. International Small Business Journal 25(5): 479-510.

Podsakoff, P.M., MacKenzie, S.B., Lee, J.Y., Podsakoff, N.P. 2003. Common method biases in behavioral research: A critical review of the literature and recommended remedies. Journal of Applied Psychology 88(5): 879-903.

Rauch, A., Frese, M. 2007. Let's put the person back into entrepreneurship research: A meta-analysis on the relationship between business owners' personality traits, business creation, and success. European Journal of Work \& Organizational Psychology 16(4): 353-385.

Rauch, A., Hulsink, W. 2014. Putting entrepreneurship education where the intention to act lies: An investigation into the impact of entrepreneurship education on entrepreneurial behavior. Academy of Management Learning \& Education.

Raudenbush, S.W., Bryk, A.S. 2002. Hierarchical linear models: Applications and data analysis methods. Sage, Newbury Park et al.

Reynolds, P., Bygrave, W., Autio, E. 2003. Global entrepreneurship monitor 2003 executive report. http://www.gemconsortium.org/docs/download/259.

Richardson, H.A., Simmering, M.J., Sturman, M.C. 2009. A tale of three perspectives: Examining post hoc statistical techniques for detection and correction of common method variance. Organizational Research Methods 12(4): 762-800.

Rosenbusch, N., Rauch, A., Bausch, A. 2013. The mediating role of entrepreneurial orientation in the task environment-performance relationship: A meta-analysis. Journal of Management 39(3): 633-659.

Sánchez, J.C. 2013. The impact of an entrepreneurship education program on entrepreneurial competencies and intention. Journal of Small Business Management 51(3): 447-465.

Scherer, R.F., Adams, J.S., Carley, S.S., Wiebe, F.A. 1989. Role model performance effects on development of entrepreneurial career preference. Entrepreneurship Theory \& Practice 13(3): 53-71.

Schlaegel, C., Koenig, M. 2014. Determinants of entrepreneurial intent: A meta-analytic test and integration of competing models. Entrepreneurship Theory and Practice 38(2): 291-332.

Scott, R. 1995. Institutions and organizations. Sage, Thousand Oaks, CA.

Shepherd, D.A. 2011. Multilevel entrepreneurship research: Opportunities for studying entrepreneurial decision making. Journal of Management 37(2): 412-420.

Snijders, T.A.B., Bosker, R.J. 1999. Multilevel analysis. Sage, London. 
Souitaris, V., Zerbinati, S., Al-Laham, A. 2007. Do entrepreneurship programmes raise entrepreneurial intention of science and engineering students? The effect of learning, inspiration and resources. Journal of Business Venturing 22(4): 566-591.

Staiger, D., Stock, J.H. 1997. Instrument variables regression with weak instruments. Econometrica 65(3): 557586.

Stel, A., Storey, D., Thurik, A. 2007. The effect of business regulations on nascent and young business entrepreneurship. Small Business Economics 28(2/3): 171-186.

Stewart Jr., W.H., Roth, P.L. 2001. Risk propensity differences between entrepreneurs and managers: A metaanalytic review. Journal of Applied Psychology 86(1): 145-153.

Tervo, H. 2006. Regional unemployment, self-employment and family background. Applied Economics 38(9): 1055-1062.

Unger, J.M., Rauch, A., Frese, M., Rosenbusch, N. 2011. Human capital and entrepreneurial success: A metaanalytical review. Journal of Business Venturing 26(3): 341-358.

Urbano, D., Alvarez, C. 2014. Institutional dimensions and entrepreneurial activity: An international study. Small Business Economics 42(4): 703-716.

Vandenberg, R.J., Lance, C.E. 2000. A review and synthesis of the measurement invariance literature: Suggestions, practices, and recommendations for organizational research. Organizational Research Methods 3(1): 4-70.

von Graevenitz, G., Harhoff, D., Weber, R. 2010. The effects of entrepreneurship education. Journal of Economic Behavior \& Organization 76(1): 90-112.

Walter, S.G., Dohse, D. 2012. Why mode and regional context matter for entrepreneurship education. Entrepreneurship \& Regional Development 24(9/10): 807-835.

Walter, S.G., Parboteeah, K.P., Walter, A. 2013. University departments and self-employment intentions of business students: A cross-level analysis. Entrepreneurship: Theory \& Practice 37(2): 175-200.

Wanous, J.P., Reichers, A.E. 1996. Estimating the reliability of a single-item measure. Psychological Reports 78(2): 631-634.

Welter, F., Smallbone, D. 2011. Institutional perspectives on entrepreneurial behavior in challenging environments. Journal of Small Business Management 49(1): 107-125.

Whitley, R. 1999. Divergent capitalism: The social structuring and change of business systems. Oxford University Press, New York.

Whitley, R. 2002. The nature of business systems and their institutional structuring. In: R. Whitley, Competing capitalisms: Institutions and economics volume i.

Williams, L.J., Hartman, N., Cavazotte, F. 2010. Method variance and marker variables: A review and comprehensive cfa marker technique. Organizational Research Methods 13(3): 477-514.

Wilson, F., Kickul, J., Marlino, D. 2007. Gender, entrepreneurial self-efficacy, and entrepreneurial career intentions: Implications for entrepreneurship education. Entrepreneurship: Theory \& Practice 31(3): 387-406.

Wooldridge, J.M. 2003. Introductory econometrics : A modern approach. South-Western College Pub., Australia ; Cincinnati, Ohio.

World Bank 2011a. Doing business- measuring business regulations. http://www.doingbusiness.org/customquery.

World Bank 2011b. World development indicators. http://data.worldbank.org/indicator, 2011-12-25. 
World Economic Forum 2010. The global competitiveness report 2010-

2011. http://www3.weforum.org/docs/WEF_GlobalCompetitivenessReport_2010-11.pdf, 2011-03-29. 

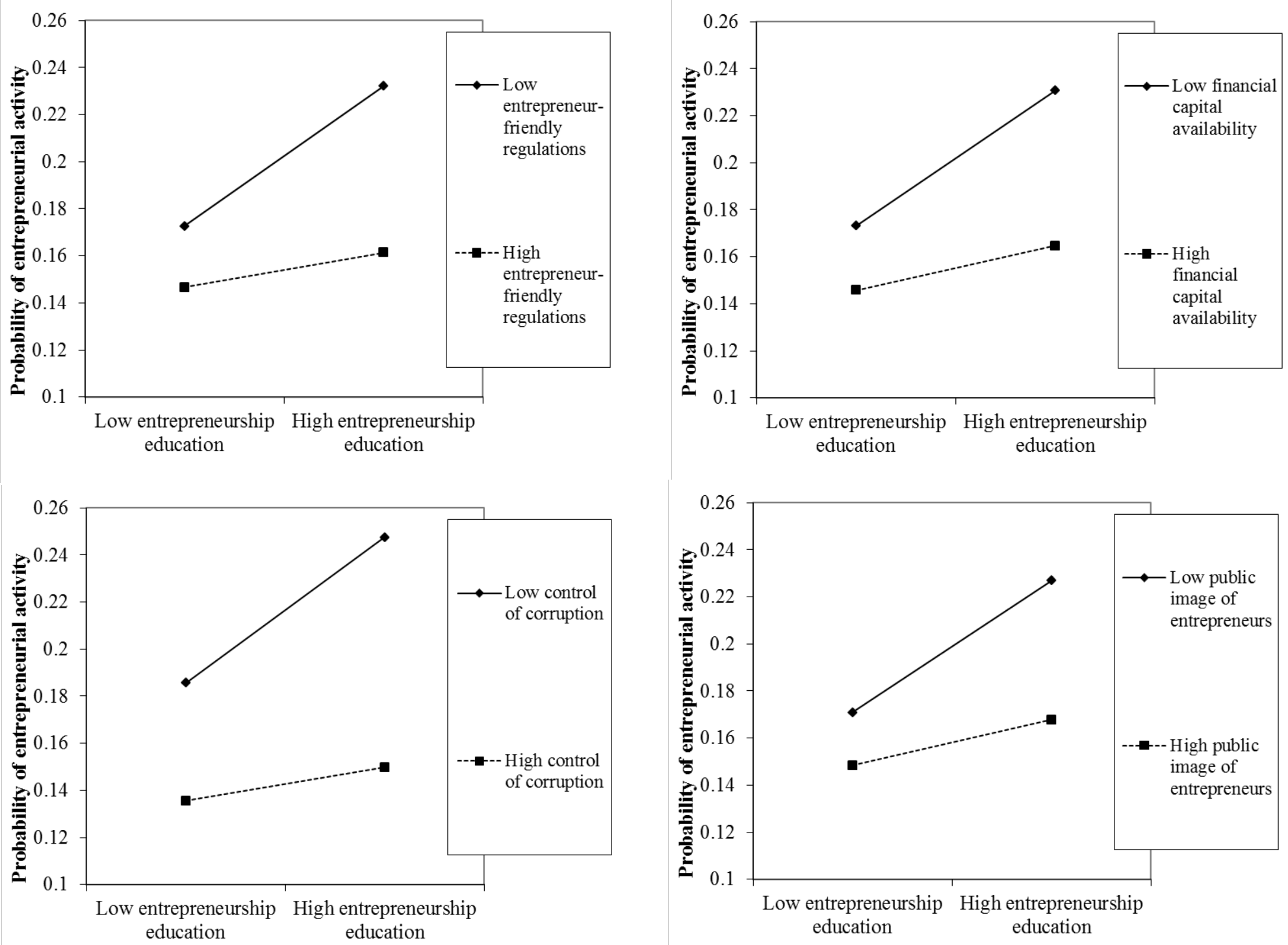

Fig. 1. Moderating effects of entrepreneur-friendly regulations, financial capital availability, control of corruption and public image of entrepreneurs. 
Table 1. Sample characteristics

\begin{tabular}{|c|c|c|c|c|c|c|c|c|c|}
\hline Nr Country & $\begin{array}{r}\text { Sample } \\
\text { size } \\
\end{array}$ & $\begin{array}{r}\text { Entr. } \\
\text { activity }^{\text {a }}\end{array}$ & $\begin{array}{r}\text { Entr. } \\
\text { education }^{\mathrm{a}}\end{array}$ & $\begin{array}{c}\text { Entr. friendly } \\
\text { regulations }\end{array}$ & $\begin{array}{r}\text { Financial cap. } \\
\text { availability }^{c}\end{array}$ & $\begin{array}{r}\text { Educational cap. } \\
\text { availability }^{\mathrm{d}}\end{array}$ & $\begin{array}{r}\text { Control of } \\
\text { corruption }\end{array}$ & $\begin{array}{r}\text { Pub. image of } \\
\text { entrepreneurs }\end{array}$ & $\begin{array}{r}\text { GDPpc } \\
(\text { ppp) } \\
\end{array}$ \\
\hline 1 Austria & 267 & 0.20 & 2.39 & 1.10 & 4.31 & 9.48 & 1.94 & 0.51 & 38822.70 \\
\hline 2 Belgium & 359 & 0.12 & 2.27 & 2.05 & 4.33 & 10.62 & 1.36 & 0.54 & 36433.14 \\
\hline 3 Bulgaria & 224 & 0.16 & 2.40 & -2.91 & 3.28 & 10.44 & -0.12 & 0.40 & 13908.33 \\
\hline 4China & 562 & 0.30 & 2.71 & -4.08 & 3.27 & 6.84 & -0.57 & 0.40 & 6811.17 \\
\hline 5 Croatia & 203 & 0.19 & 2.42 & -3.39 & 3.27 & 10.60 & 0.05 & 0.32 & 19999.78 \\
\hline 6 Cyprus & 247 & 0.26 & 2.59 & 0.18 & 3.94 & 9.39 & 1.04 & 0.48 & 28557.98 \\
\hline 7 Czech Republic & 467 & 0.22 & 2.34 & -3.97 & 3.60 & 13.07 & 0.33 & 0.42 & 25578.46 \\
\hline 8Denmark & 326 & 0.10 & 2.31 & 3.21 & 4.81 & 11.17 & 2.46 & 0.83 & 37845.50 \\
\hline 9 Estonia & 251 & 0.16 & 2.26 & -0.58 & 4.34 & 12.09 & 0.92 & 0.54 & 19698.54 \\
\hline 10 Finland & 245 & 0.25 & 2.47 & 3.54 & 5.11 & 9.79 & 2.39 & 0.81 & 35259.67 \\
\hline 11 France & 512 & 0.11 & 2.17 & 1.38 & 4.43 & 10.06 & 1.40 & 0.61 & 34787.54 \\
\hline 12 Germany & 509 & 0.19 & 2.28 & 1.78 & 4.26 & 11.86 & 1.76 & 0.44 & 36372.33 \\
\hline 13 Greece & 494 & 0.32 & 2.18 & -3.56 & 3.77 & 9.67 & 0.21 & 0.40 & 29677.60 \\
\hline 14 Hungary & 431 & 0.18 & 2.15 & -1.38 & 3.50 & 11.70 & 0.49 & 0.29 & 20296.14 \\
\hline 15 Iceland & 360 & 0.18 & 2.58 & 2.94 & 4.41 & 10.03 & 2.22 & 0.86 & 36802.64 \\
\hline 16 Ireland & 242 & 0.21 & 2.27 & 2.48 & 4.43 & 11.67 & 1.64 & 0.66 & 40619.39 \\
\hline 17 Italy & 532 & 0.24 & 2.26 & -2.24 & 3.29 & 9.02 & 0.18 & 0.62 & 32684.65 \\
\hline 18 Japan & 442 & 0.22 & 2.19 & 1.33 & 4.20 & 11.16 & 1.31 & 0.32 & 32426.05 \\
\hline 19 Latvia & 194 & 0.14 & 2.01 & -0.35 & 3.36 & 10.10 & 0.20 & 0.52 & 14305.72 \\
\hline 20 Lithuania & 247 & 0.15 & 2.24 & -0.62 & 3.88 & 10.62 & 0.17 & 0.47 & 17362.86 \\
\hline 21 Luxembourg & 243 & 0.14 & 2.29 & -0.06 & 4.77 & 10.34 & 1.94 & 0.59 & 84645.70 \\
\hline 22 Netherlands & 537 & 0.19 & 2.35 & 2.67 & 4.90 & 11.07 & 2.11 & 0.58 & 40679.30 \\
\hline 23 Norway & 316 & 0.14 & 2.44 & 2.95 & 5.11 & 11.91 & 2.00 & 0.65 & 56541.95 \\
\hline 24 Poland & 450 & 0.25 & 2.37 & -4.02 & 3.68 & 10.91 & 0.28 & 0.32 & 18896.86 \\
\hline 25 Romania & 161 & 0.15 & 2.65 & -2.49 & 3.33 & 10.37 & -0.20 & 0.50 & 14286.24 \\
\hline 26 Slovenia & 189 & 0.13 & 2.36 & -2.19 & 3.81 & 11.76 & 0.96 & 0.42 & 27149.46 \\
\hline 27 South Korea & 270 & 0.41 & 2.49 & -0.49 & 3.86 & 11.25 & 0.44 & 0.31 & 27099.95 \\
\hline 28 Spain & 525 & 0.19 & 2.49 & -2.60 & 3.94 & 10.00 & 1.13 & 0.49 & 31607.75 \\
\hline 29 Sweden & 245 & 0.11 & 2.26 & 2.45 & 5.01 & 11.97 & 2.21 & 0.56 & 37698.17 \\
\hline 30 Switzerland & 247 & 0.19 & 2.48 & 1.88 & 4.51 & 11.13 & 2.10 & 0.56 & 44910.96 \\
\hline 31 United Kingdom & 443 & 0.17 & 1.99 & 2.14 & 4.90 & 11.05 & 1.72 & 0.49 & 35182.76 \\
\hline 32 USA & 490 & 0.29 & 2.74 & 2.84 & 5.04 & 13.14 & 1.43 & 0.75 & 45934.27 \\
\hline
\end{tabular}

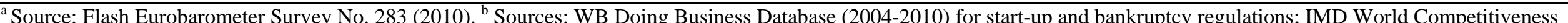

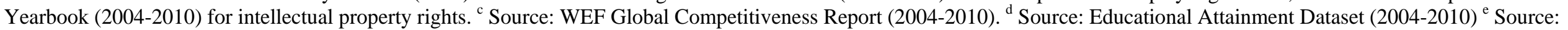

WB World Governance Indicators (2004-2010). 
Table 2. Results for tests of measurement invariance

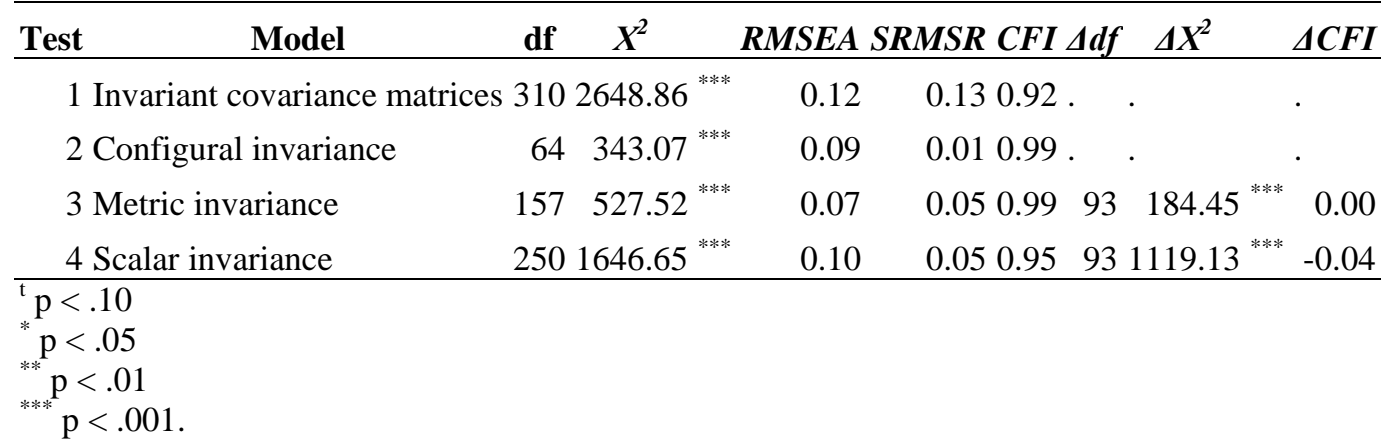


Table 3. Descriptive statistics and correlations ${ }^{\mathrm{a}}$

\begin{tabular}{|c|c|c|c|c|c|c|c|c|c|c|c|c|c|c|c|c|c|c|c|c|}
\hline Variable & Mean & SD 1 & 2 & 3 & 4 & 5 & 6 & 7 & 8 & 9 & 10 & 11 & 12 & 13 & 14 & 15 & 16 & 17 & 18 & 19 \\
\hline \multicolumn{21}{|l|}{ Individual level } \\
\hline 1.Entrepreneurial activity & .20 & $.40-$ & & & & & & & & & & & & & & & & & & \\
\hline 2.Entrepreneurship education & 2.35 & $.71 .09^{* * *}$ & - & & & & & & & & & & & & & & & & & \\
\hline \multicolumn{21}{|l|}{ Country level } \\
\hline 3.Entrepreneur-friendly regulations & .00 & $2.51-.06^{* * *}$ & $-.02^{*}$ & - & & & & & & & & & & & & & & & & \\
\hline 4.Financial capital availability & 4.15 & $.61-.05^{* * *}$ & -.01 & $.86^{* * *}$ & * & & & & & & & & & & & & & & & \\
\hline 5.Educational capital availability & 1.76 & $1.23-.04^{* * *}$ & $-.05^{* * *}$ & .28 & $.37^{*}$ & - & & & & & & & & & & & & & & \\
\hline 6.Control of corruption & 1.11 & $.88-.08^{* * *}$ & $-.03^{* *}$ & $.88^{* * *}$ & $.91^{* * *}$ & .29 & - & & & & & & & & & & & & & \\
\hline 7.Public image of entrepreneurs & .52 & $.15-.05^{* * *}$ & $.06^{* * *}$ & $.69^{* * *}$ & $.65^{* * *}$ & .03 & $.66^{* * *}$ & - & & & & & & & & & & & & \\
\hline \multicolumn{21}{|l|}{ Control variables } \\
\hline 8.Gdp (ppp) per capita & $31,965.11$ & $14,592.96-.04^{* * *}$ & $-.02^{\mathrm{t}}$ & $.57^{* * *}$ & $.73^{* * *}$ & .24 & $.73^{* * *}$ & $.48^{* *}$ & - & & & & & & & & & & & \\
\hline 9.Age & 43.85 & $10.96 .09^{* * *}$ & $-.03^{* * *}$ & $.15^{* * *}$ & *. $.12^{* * *}$ & $.17^{* * *}$ & * $.14^{* * *}$ & $.05^{* * *}$ & $.09^{* * *}$ & * - & & & & & & & & & & \\
\hline 10.Male & .47 & $.50 .13^{* * *}$ & $.06^{* * *}$ & .00 & .00 & $-.04^{* * *}$ & * .00 & .01 & .00 & $-.02^{\mathrm{t}}$ & - & & & & & & & & & \\
\hline 11.Education level & 14.28 & $3.23-.02^{*}$ & $.15^{* * *}$ & $.09^{* * *}$ & $.11^{* * *}$ & $.08^{* * *}$ & $.09^{* * *}$ & $.14^{* * *}$ & $.07^{* * *}$ & * $-.07^{* * *}$ & $* 01$ & - & & & & & & & & \\
\hline 12.Self-employed father & .24 & $.43 .15^{* * *}$ & $.06^{* * *}$ & $.04^{* * *}$ & $.05^{* * *}$ & $-.09^{* * *}$ & * $.06^{* * *}$ & $.02^{*}$ & $.05^{* * *}$ & $* .00$ & $.02^{\mathrm{t}}$ & .01 & - & & & & & & & \\
\hline 13.Self-employed mother & .12 & $.33 .14^{* * *}$ & $.06^{* * *}$ & $-.03^{* *}$ & $-.03^{* *}$ & $-.16^{* * *}$ & ${ }^{*}-.04^{* * *}$ & $-.05^{* * *}$ & $-.05^{* * *}$ & $*-.01$ & .00 & $-.04^{* * *}$ & $.46^{* * *}$ & - & & & & & & \\
\hline 14.Risk tolerance & 2.77 & $.79 .11^{* * *}$ & $.16^{* * *}$ & * -.01 & $.03^{* * *}$ & $-.03^{* *}$ & -.01 & $.09^{* * *}$ & $.04^{* * *}$ & $*-.09^{* * *}$ & ${ }^{*} .10^{* * *}$ & $.06^{* * *}$ & $.03^{* * *}$ & .01 & - & & & & & \\
\hline 15.Self-confidence & 3.12 & $.63 .05^{* * *}$ & $.11^{* * *}$ & $.07^{* * *}$ & $.08^{* * *}$ & .01 & $.04^{* * *}$ & $.10^{* * *}$ & $.04^{* * *}$ & $*-.02^{*}$ & $.05^{* * *}$ & $.05^{* * *}$ & .01 & .00 & $.26^{* * *}$ & * & & & & \\
\hline 16.Internal locus of control & 3.18 & $.70 .04^{* * *}$ & $.10^{* * *}$ & $.04^{* * *}$ & $.05^{* * *}$ & $.03^{* *}$ & .01 & $.07^{* * *}$ & $.02^{*}$ & $-.03^{* *}$ & .01 & .02 & .00 & -.01 & $.16^{* * *}$ & $.29^{* * *}$ & * - & & & \\
\hline 17.Inventiveness & 3.07 & $.69 .09^{* * *}$ & $.16^{* * *}$ & .02 & $.03^{* *}$ & $-.02^{\mathrm{t}}$ & $.03^{* *}$ & $.09^{* * *}$ & $.05^{* * *}$ & ${ }^{*}-.04^{* * *}$ & ${ }^{*} .06^{* * *}$ & $.09^{* * *}$ & $.02^{\mathrm{t}}$ & .00 & $.28^{* * *}$ & $.31^{* * *}$ & ${ }^{*} .22^{*}$ & ${ }^{*}-$ & & \\
\hline 18.Desire for competition & 2.63 & $.84 .07^{* * *}$ & $.18^{* * *}$ & .00 & .01 & $-.07^{* * *}$ & ${ }^{*}-.04^{* * *}$ & $.09^{* * *}$ & $.02^{\mathrm{t}}$ & $-.09^{* * *}$ & ${ }^{*} .19^{* * *}$ & * .00 & $.02^{* *}$ & .00 & $.30^{* * *}$ & $.22^{* * *}$ & ${ }^{*} .16^{*}$ & $.22^{* * *}$ & * - & \\
\hline 19.Proactivity & 3.07 & $.66 .06^{* * *}$ & $.11^{* * *}$ & $.06^{* * *}$ & $.09^{* * *}$ & $.06^{* * *}$ & * $.07^{* * *}$ & $.09^{* * *}$ & $.11^{* * *}$ & ${ }^{*}-.03^{* *}$ & $.04^{* * *}$ & $.03^{* * *}$ & .01 & $-.02^{*}$ & $.22^{* * *}$ & $.29^{* * *}$ & ${ }^{*} .27^{*}$ & $.28^{* * *}$ & $.20^{* * *}$ & * - \\
\hline 20.Optimism & 3.06 & $.75 .05^{* * *}$ & $.15^{* * *}$ & $.11^{* * *}$ & $.15^{* * *}$ & $.06^{* * *}$ & $.12^{* * *}$ & $.13^{* * *}$ & $.10^{* * *}$ & * $-.06^{* * *}$ & ${ }^{*} .02^{*}$ & $.11^{* * *}$ & $.02^{*}$ & $.02^{\mathrm{t}}$ & $.22^{* * *}$ & $.30^{* * *}$ & ${ }^{*} .25^{*}$ & ${ }^{* *} .27^{* * *}$ & ${ }^{*} .20^{* * *}$ & ${ }^{*} .23^{* * *}$ \\
\hline
\end{tabular}

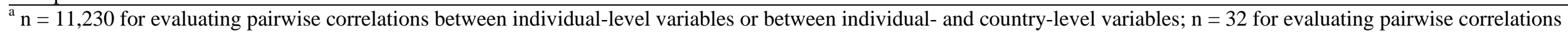
between country-level variables.

${ }_{*}^{\mathrm{t}} \mathrm{p}<.10$

${ }_{* *}^{*} \mathrm{p}<.05$

${ }^{* *} \mathrm{p}<.01$

${ }^{* * *} \mathrm{p}<.001$ (two-tailed test). 
Table 4. Results of hierarchical generalized linear models for entrepreneurial activity (log-odds) ${ }^{\mathrm{a}}$

\begin{tabular}{|c|c|c|c|c|c|c|c|c|c|c|c|c|}
\hline \multirow{2}{*}{ 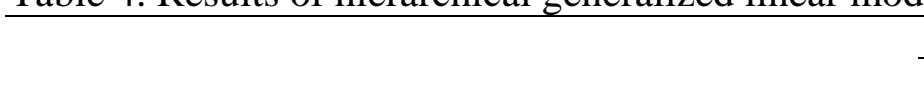 } & \multicolumn{2}{|l|}{ Model 1} & \multicolumn{2}{|l|}{ Model 2} & \multicolumn{2}{|c|}{ Model 3} & \multicolumn{2}{|l|}{ Model 4} & \multicolumn{2}{|l|}{ Model 5} & \multicolumn{2}{|l|}{ Model 6} \\
\hline & B & S.E. & B & S.E. & B & S.E. & B & S.E. & B & S.E. & B & S.E. \\
\hline \multicolumn{13}{|l|}{ Control variables (individual level) } \\
\hline Age & $.03^{* * *}$ & .00 & $.03^{* * *}$ & .00 & $.03^{* * *}$ & .00 & $.03^{* * *}$ & .00 & $.03^{* * *}$ & .00 & $.03^{* * *}$ & .00 \\
\hline Male & $.62^{* * *}$ & .06 & $.62^{* * *}$ & .06 & $.62^{* * *}$ & .06 & $.63^{* * *}$ & .06 & $.62^{* * *}$ & .06 & $.63^{* * *}$ & .06 \\
\hline Education level & -.02 & .01 & -.02 & .01 & $-.02^{t}$ & .01 & -.02 & .01 & $-.02^{\mathrm{t}}$ & .01 & -.02 & .01 \\
\hline Self-employed father & $.58^{* * *}$ & .06 & $.57^{* * *}$ & .06 & $.58^{* * *}$ & .06 & $.57^{* * *}$ & .06 & $.57^{* * *}$ & .06 & $.57^{* * *}$ & .06 \\
\hline Self-employed mother & $.46^{* * *}$ & .07 & $.45^{* * *}$ & .07 & $.46^{* * *}$ & .07 & $.46^{* * *}$ & .07 & $46^{* * *}$ & .07 & $46^{* * *}$ & .07 \\
\hline Risk tolerance & $.28^{* * *}$ & .05 & $.27^{* * *}$ & .05 & $.27^{* * *}$ & .05 & $.27^{* * *}$ & .05 & $.27^{* * *}$ & .05 & $.27^{* * *}$ & .05 \\
\hline Self-confidence & -.04 & .05 & -.04 & .05 & -.04 & .05 & -.04 & .05 & -.04 & .05 & -.04 & .05 \\
\hline Internal locus of control & .05 & .05 & .05 & .05 & .05 & .05 & .05 & .05 & .05 & .05 & .05 & .05 \\
\hline Inventiveness & $.20^{* * *}$ & .03 & $.19^{* * *}$ & .03 & $.19^{* * *}$ & .03 & $.19^{* * *}$ & .03 & $.19^{* * *}$ & .03 & $.19^{* * *}$ & .03 \\
\hline Desire for competition & .00 & .03 & -.01 & .03 & -.01 & .03 & -.01 & .03 & -.01 & .03 & -.01 & .03 \\
\hline Proactivity & $.11^{* * *}$ & .03 & $.10^{* * *}$ & .03 & $.10^{* * *}$ & .03 & $.10^{* * *}$ & .03 & $.10^{* * *}$ & .03 & $.10^{* * *}$ & .03 \\
\hline Optimism & .05 & .05 & .05 & .06 & .05 & .05 & .04 & .06 & .05 & .05 & .04 & .05 \\
\hline \multicolumn{13}{|l|}{ Control variable (country level) } \\
\hline Gdp (ppp) per capita & $.00^{*}$ & .00 & $.00^{*}$ & .00 & .00 & .00 & .00 & .00 & .00 & .00 & .00 & .00 \\
\hline \multicolumn{13}{|l|}{ Main effect (individual level) } \\
\hline Entrepreneurship education & & & $.18^{* * *}$ & .05 & & & $.16^{* * *}$ & .04 & $.18^{* * *}$ & .05 & $.17^{* * *}$ & .04 \\
\hline \multicolumn{13}{|l|}{ Main effects (country level) } \\
\hline Entrepreneur-friendly regulations & & & & & $-.06^{*}$ & .03 & $-.05^{*}$ & .03 & & & & \\
\hline Financial capital availability & & & & & & & & & -.21 & .15 & -.20 & .15 \\
\hline \multicolumn{13}{|l|}{ Educational capital availability } \\
\hline \multicolumn{13}{|l|}{ Control of corruption } \\
\hline \multicolumn{13}{|l|}{ Public image of entrepreneurs } \\
\hline \multicolumn{13}{|l|}{ Interaction effects (cross-level) } \\
\hline Entrepreneurship education X entrepreneur-friendly regulations & & & & & & & $-.04^{* *}$ & .01 & & & & \\
\hline Entrepreneurship education X financial capital availability & & & & & & & & & & & $-.14^{*}$ & .07 \\
\hline Entrepreneurship education X educational capital availability & & & & & & & & & & & & \\
\hline Entrepreneurship education X control of corruption & & & & & & & & & & & & \\
\hline Entrepreneurship education $\mathrm{X}$ public image of the entrepreneur & & & & & & & & & & & & \\
\hline Deviance & 31022.74 & & 30999.05 & & 30995.13 & & 30986.99 & & 30996.75 & & 30991.54 & \\
\hline Deviance difference (Chi-sqr) & $710.44^{* * *}$ & & $734.13^{* * *}$ & & $738.04^{* * *}$ & & $746.19^{\text {*** }}$ & & $736.43^{* * *}$ & & $741.64^{* * *}$ & \\
\hline
\end{tabular}

${ }^{\mathrm{a}}$ Individual-level $\mathrm{n}=11,230$; country-level $\mathrm{n}=32$. Robust standard errors are reported.

${ }^{\mathrm{t}} \mathrm{p}<.10 ;{ }^{*} \mathrm{p}<.05 ;{ }^{* *} \mathrm{p}<.01 ;{ }^{* * *} \mathrm{p}<.001$ (two-tailed test). 
Table 4. Results of hierarchical generalized linear models for entrepreneurial activity (log-odds) ${ }^{\mathrm{a}}$ (cont'd)

\section{Model 7}

$$
\text { B }
$$

S.E.

\section{Model 8}

Control variables (individual level)

Age

Male

Education level

Self-employed father

Self-employed mother

Risk tolerance

Self-confidence

Internal locus of control

Inventiveness

Desire for competition

Proactivity

Optimism

Control variable (country level)

Gdp (ppp) per capita

Main effect (individual level)

Entrepreneurship education

Main effects (country level)

Entrepreneur-friendly regulations

Financial capital availability

Educational capital availability

Control of corruption

Public image of entrepreneurs

Interaction effects (cross-level)

Entrepreneurship education X entrepreneur-friendly regulations

Entrepreneurship education X financial capital availability

Entrepreneurship education X educational capital availability

Entrepreneurship education X control of corruption

$.01 \quad .04$

Entrepreneurship education $\mathrm{X}$ public image of the entrepreneur

Deviance

Deviance difference (Chi-sqr)

Individual-level $\mathrm{n}=11,230$

$\begin{array}{llll}.03^{* * *} & .00 & .03^{* * *} & .00 \\ .62^{* * *} & .06 & .62^{* * *} & .06 \\ -.02^{\mathrm{t}} & .01 & -.02^{\mathrm{t}} & .01 \\ .57^{* * *} & .06 & .57^{* * *} & .06 \\ .45^{* * *} & .07 & .45^{* * *} & .07 \\ .27^{* * *} & .05 & .27^{* * *} & .05 \\ .04 & .05 & -.04 & .05 \\ .05 & .05 & .05 & .05 \\ .19^{* * *} & .03 & .19^{* * *} & .03 \\ .01^{* * *} & .03 & -.01 & .03 \\ .10^{* * *} & .03 & .10^{* * *} & .03 \\ .05 & .06 & .05 & .06\end{array}$

Model 9

Model 10

Model 11

\section{B}

S.E.

Model 12

B S.E.

B S.E

$.03^{* * *} .00$

$.62^{* * *} .06$

$-.02^{\mathrm{t}} \quad .01$

$.58^{* * *} .06$

$.46^{* * *} .07$

$.27^{* * *} .05$

$-.04 \quad .05$

$.05 \quad .05$

$.19^{* * *} .03$

$-.01 \quad .03$
.10

$.10^{* * *} .03$

$.05 \quad .05$

$.03^{* * *} .00$

$.63^{* * *} .06$

$-.02 \quad .01$

$.58^{* * *} .06$

$.46^{* * *} .07$

$.27^{* * *} .05$

$\begin{array}{ll}-.04 & .05\end{array}$

$.04 \quad .05$

$.19^{* * *} .03$

$-.01 \quad .03$
.10

$.10^{* * *} .03$

$.04 \quad .05$

$.00^{* *} .00$

$.00^{* *} \quad .00$

$.00 \quad .00$

$.00 \quad .00$

$.03^{* * *} .00$

$.62^{* * *} .06$

$-.02^{\mathrm{t}} \quad .01$

$.57^{* * *} .06$

$.46^{* * *} .07$

$.27^{* * *} .05$

$\begin{array}{ll}-.04 & .05\end{array}$

$.05 \quad .05$

$.19^{* * *} .03$

$\begin{array}{ll}-.01 & .03\end{array}$

$.10^{* * *} .03$

$.05 \quad .05$

$.00 \quad .00$

$.16^{* * *} .04$

$.18^{* * *} .05$

.00

.05

.00

.05

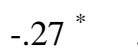

$-.26^{*}$

.10

$-.68 \quad .57$

$-66$

$\mathrm{p}<.10 ;{ }^{*} \mathrm{p}<.05 ;{ }^{* *} \mathrm{p}<.01 ;{ }^{* * *} \mathrm{p}<.001$ (two-tailed test).
$-.11^{*} \quad .04$

$-.53^{* *}$

30999.03

30998.75

30992.21

$740.97^{* * *}$

30985.93 $747.25^{* * *}$

30996.53

30991.77
$736.65^{* * *}$

\section{.E.}

$.03^{* * *} .00$

$\begin{array}{ll}. .02 & .01\end{array}$

$.57^{* * *} .06$

$27^{* * *} \quad .05$

$-.04 \quad .05$

.05 *** .05

$-.01 \quad .03$

$.10^{* * *} .03$

$.00 \quad .00$

04

-

747.25

근

